\title{
BIMBY's first steps: a pilot study on the contribution of residential front-yards in Phoenix and Maastricht to biodiversity, ecosystem services and urban sustainability
}

\author{
Carijn Beumer $^{1}$ (D) Pim Martens ${ }^{1}$
}

Published online: 20 August 2015

C) The Author(s) 2015. This article is published with open access at Springerlink.com

\begin{abstract}
Large parts of urban space around the world exist of small-scale plots such as domestic gardens. These small-scale urban spaces carry potential for enhancing biodiversity, sustainability and ecosystem services in and beyond cities. However, domestic gardening and residential garden designs are often guided by aesthetics and ease more than by the aim to create habitat and biological diversity. Yard-management decisions impact socio-ecological systems in various ways, for example through irrigation patterns, fertilization or the use of pesticides or through the choice for exotic species that may become invasive over time. Yardmanagement decisions can also positively influence the presence of pollinators, improve soil quality or even foster small scale 'Wildlife Habitats' that can function as ecological stepping stones to the wider environment. In this paper a pilot assessment is presented of the contribution of residential front-yards in Phoenix (Arizona) and Maastricht (The Netherlands) to biodiversity, ecosystem services and sustainability by applying the BIMBY (Biodiversity in My (Back) Yard) framework.
\end{abstract}

Keywords Biodiversity · Domestic yards · Sustainability · Ecosystem services · Garden design · Residential environment

\section{Introduction}

As more than half of the world population lives in cities (UNEP 2014) it will be increasingly important to reconcile ecological aspects, design, and human lifestyle-practices in urban environments (Rosenzweig 2003; Cilliers 2010). Large parts of urban space in many countries exist of gardens, patios, courtyards, balconies and roof-terraces (Lubbe et al. 2010). This

Carijn Beumer

carijn.beumer@maastrichtuniversity.nl

1 International Centre for Integrated assessment and Sustainable Development (ICIS), Maastricht University, P.O. 616, 6200 MD Maastricht, The Netherlands 
means there is a great - and still largely unexplored - social, cultural and ecological potential for residential gardens to contribute to biodiversity, ecosystem services and sustainability in urban realms and beyond (Galluzzi et al. 2010; Goddard et al. 2010; Lubbe et al. 2010; Chowdhury et al. 2011; Cook et al. 2012; Heezik et al. 2012; Zwaagstra 2014; Beumer and Martens 2015). Citizens can become important agents in creating thriving, well-connected living environments (Rudd et al. 2002). Still, residential garden designs and maintenance styles are often guided by aesthetics and ease more than by the aim to create habitat, to increase biodiversity, to build capacities for (urban) sustainability, or for the delivery of ecosystem services (Cranz and Boland 2004; Martin 2008; Ignatieva 2010; Beumer 2014; Beumer and Martens 2015).

In this paper a pilot assessment is presented of the way front-yards in Phoenix (Arizona, US) and Maastricht (The Netherlands) contribute to biodiversity, ecosystem services and sustainable (urban) environments through applying the BIMBY indicator framework (Biodiversity In My (Back) Yard) (Beumer and Martens 2015). With this framework we intend to contribute to a young field of study that aims to bridge ecological and socio-cultural disciplines (Chowdhury et al. 2011; Cook et al. 2012; Uren et al. 2015). There is still a gap with regards to an integrated understanding of domestic urban space and how it is constituted through an interaction of natural and human factors (Larson et al. 2010; Lubbe et al. 2010; Chowdhury et al. 2011; Cook et al. 2012; Beumer and Martens 2015; Uren et al. 2015). On a societal level, the framework aims to foster a transformational dialogue (Lang et al. 2012; Wiek et al. 2012) on the question: how can we reconcile living comfort, aesthetics and ease at the one hand and the protection of biodiversity, ecosystem services and a sustainable living environment at the other hand, in the way we design our residential areas (Rosenzweig 2003)?

Most earlier research on the household-parcel scale has focused on either ecological garden-structures and -features (e.g. Cornelis and Hermy 2004; Gaston et al. 2005; Hope et al. 2006; Baker and Harris 2007; Burghardt et al. 2008; Loram et al. 2008; Martin 2008; Kendal et al. 2012), or on factors that influence human choices and preferences for certain types of yards (Nassauer 1995; Larsen and Harlan 2006; Larsen and Swanbrow 2006; Lyytimäki et al. 2008; Larson et al. 2009; St. Hilaire et al. 2010; Zheng et al. 2011; Heezik, et al. 2012; Kurz and Baudains 2012; Uren, et al. 2015). Although urban residential landscapes and domestic gardening preferences, values and drivers are increasingly studied in the context of sustainable development and biodiversity conservation (Miller and Hobbs 2002; Gaston, et al. 2005; Larsen and Harlan 2006; Mathieu et al. 2007; Loram et al. 2008; Galluzzi et al. 2010; Goddard et al. 2010; Larson et al. 2010; St. Hilaire et al. 2010; Chowdhury et al. 2011; Zheng et al. 2011; Cook et al. 2012; Heezik et al. 2012; Kurz and Baudains 2012) there is still much to be learned on how cultural elements and human preferences represented in domestic gardens (e.g. design style, maintenance need, artefacts) influence habitat value, biodiversity, ecosystem services, and sustainability in and beyond human settlement areas (Dunn et al. 2006; Galluzzi et al. 2010; Larson et al. 2010; Chowdhury et al. 2011; Cook et al. 2012; Heezik et al. 2012). Integrative approaches that combine ecological and cultural factors in domestic landscaping practices and design are available but scarce (Larson et al. 2010; Lubbe et al. 2010; Cook et al. 2012; Uren et al. 2015).

Through a combination of observational field-visits, photo-analyses and literature study (Noss 1990; Costanza et al. 1997; Opschoor 1998; Bolund and Hunhammar 1999; Hermy and Cornelis 2000; Savard 2000; Nunes and van den Bergh 2001; Appleton 2002; Groot et al. 2002; McKinney 2002; Nagendra 2002; Spellerberg and Ferdor 2003; Zerbe et al. 2003; Cornelis and Hermy 2004; Gaston et al. 2005; Keylock 2005; McNeely et al. 2005; MEA 2005; Larsen and Harlan 2006; Baker and Harris 2007; CBD 2007; Hart 2007; Norton and 
Noonan 2007; Loram et al. 2008; Lyytimäki et al. 2008; Martin 2008; Sukopp 2008; Dearborn and Kark 2009; TEEB 2009; Caro 2010; Galluzzi et al. 2010; Hancock 2010; Larson et al. 2010; Müller et al. 2010; St. Hilaire, et al. 2010; Tzoulas and James 2010; Beatley 2011; Farinha-Marques et al. 2011; Müller and Kamada 2011; Cook et al. 2012; Jaganmohan et al. 2012; Jim 2012; Jorgensen and Keenan 2012; Kendal et al. 2012; Kurz and Baudains 2012; Shin 2012; Qviström 2013), the results presented in this paper deliver insights into patterns of yard-contributions to biodiversity, related ecosystem services and disservices, and the sustainability of the urban and even regional environment. Our understanding of ecosystem services is based on the work of Costanza and his colleagues (1997, 2014), the framework provided by the Millennium Ecosystem Assessment (MEA 2005), and the more recent TEEB research (TEEB 2009, 2011). Biodiversity can be defined as the variety of living species, populations, communities and genetic material and their functional relations (CBD 2010; IUCN 2013). It is constitutive to the supporting services within the ecosystem services framework, contributing to provisioning, regulating and cultural services (MEA 2005). With the ambiguous term 'sustainability' we refer to an ideal of long-term socio-ecological well-being grounded in environmental resilience (Gunderson and Holling 2002; Folke et al. 2004; Olsson and Folke 2007; Rees 2010; Tidball 2012; Meijer et al. 2013).

\section{Methodology}

The methodology used for the pilot study is based on observational field visits of front-yards $(N=512)$ in Phoenix, Arizona and in Maastricht, the Netherlands, photo-analyses, and a qualitative evaluation of the data in the context of ecosystem services and sustainability. Phoenix and Maastricht were chosen as case cities because different determinants give them different characters (see Table 1).

Next to the differences, both cities have residential areas with often spacious front- and back-yards. Both cities are also surrounded and intercepted by natural and/or semi-natural

Table 1 Case city comparisons

\begin{tabular}{lll}
\hline Determinant & Maastricht & Phoenix \\
\hline Climate & Temperate & Arid Desert \\
Vegetation & Deciduous green & Warm desert scrub \\
Number of inhabitants & 120.000 inhabitants (small) & 1.500 .000 .000 inhabitants (large) \\
Population & High population density & Dispersed residential environment \\
City age & Roman and Medieval European & Young city founded in 1861 \\
& history & \\
City size & 60.06 km & \\
Urban space & Compact city & 1338 km \\
Residential areas & Planned neighbourhoods and & Urban sprawl \\
Urban downtown character & agglomerate villages & Suburbs \\
Dominant culture & Historical core & Metropolitan high-rise \\
& Western European & North American \& Latin American \\
\hline
\end{tabular}

\footnotetext{
a Data from CBS (2013)

${ }^{\mathrm{b}}$ Data from USCB (2013)
} 
landscapes and parks that give habitat to native wildlife and plant-species. These natural areas also provide access-routes for wild animal species into the residential areas. Within each city a broad comparability of socio-economic status in the neighbourhoods (High, Mid-Range, Average, and Low) was chosen as a selection criterion for the neighbourhoods (Hope et al. 2006; Martin 2008) (see Table 2). The information on socio-economic status was derived from real-estate websites. House prices were compared to each country's modal income.

The data were gathered by the lead author through sensory observation and by taking photos of the front-yards in April and May 2013. The sensory information (visual, auditory, scents, temperature, moisture, neighbourhood context) was gathered by observation on the level of the visited neighbourhoods, paying attention to present animal species, sounds of animals or potential disturbances (i.e. traffic sounds, motorised yard maintenance noise), smells (i.e. air pollution, flowers, artificial fertiliser), temperature (subjective temperature and comfort), moisture (i.e. wet or moist irrigated lawns, dusty barren soil) and neighbourhood context (i.e. close to busy roads, parks). This information was gathered in a notebook and it served as contextual information to help interpret the contribution of front-yards to biodiversity and ecosystem services on the neighbourhood scale.

Next to the sensory observation, photos of the yards have been taken for later analysis. Photos have been used before in qualitative and quantitative ways: in preference studies (Ewing 2001; White et al. 2009) and in (socio)-ecological research both inside and outside urban residential areas (Mathieu, et al. 2007; Ahrends et al. 2009; Zheng et al. 2011). Ecologists often use aerial photographs (Vellend et al. 2013; Zarco-Tejada et al. 2013; Beck et al. 2014; Zwaagstra 2014). Aerial photos lack a lot of detail and three-dimensionality that only becomes visible on the ground. In our study multiple photos were taken inside each frontyard of random streets in the neighbourhoods. The pictures were taken from different viewpoints: at least one picture provided a general overview of the front-yard. This overview picture had to capture the approximate size of the garden, the distribution of green coverage versus sealed soils, the vertical diversity of the plantation, and a general view of the garden design style. Complementary pictures were taken to zoom into relevant details (e.g. specific plant species and varieties, furniture, gardening equipment or tools, irrigation systems, damages, signs of herbicide or pesticide use, animal species, forage stations, nesting, water features). The amount of pictures taken for each yard depended on the amount of relevant details. The information delivered by the sensory observations and the photographs were categorized according to the BIMBY indicator framework (Beumer and Martens 2015) and analysed using IBM SPSS Statistics 19. This resulted into an indication of the contribution or dis-contribution of the yards to biodiversity on a neighbourhood level and on the city level (Total Diversity).

Table 2 Selection of neighbourhoods in Maastricht and Phoenix

\begin{tabular}{lllll}
\hline Socio-economic status & Maastricht & Number of yards & Phoenix & Number of yards \\
\hline High & Sint Pieter & $N=80$ & Palmcroft & $N=44$ \\
Mid-range & Vroendaal & $N=51$ & Santo Tomas & $N=56$ \\
Average & De Heeg & $N=121$ & Fairview Place & $N=73$ \\
Low & Blauwdorp & $N=76$ & Lancaster Manors & $N=11$ \\
& Total & $N=328$ & Total & $N=184$ \\
\hline
\end{tabular}


The number of the photographed front-yards varies per neighbourhood due to neighbourhood size, density of yards and safety of entering the neighbourhood. The latter resulted into a low number of photographed yards $(n=11)$ for Phoenix Low (see Table 2). The lead author did not feel safe there as certain residents shouted and signed to move on. The decision has been made to keep Phoenix Low in the sample, being aware that the neighbourhood data are not statistically representative. They still provide some valuable information that qualitatively contributes to the assessments in this paper.

In order to prepare the analysis on the city level ${ }^{1}$ and on the neighbourhood level levels, the goodness of fit of a normal model to the data was assessed with descriptive statistics in IBM SPSS 19 for these levels and for the total sample as well by making histograms and normal QQ plots (Pallant 2005) (see Appendix 1). The tests showed a normal distribution with the exception of a deviation in Phoenix Low (small sample) and Phoenix Average (two outliers) (see Fig. 1).

Assessing the range of the Total Diversity (TD) of the neighbourhoods and the outliers in Phoenix Average (see Fig. 1) made us decide to keep them in the sample. Yard number 297 gives a value for a particular and highly diverse garden with a permaculture-edible design. The garden has an official certification as Wildlife Habitat (NWF 2013). These certificates are provided by the National Wildlife Federation in order to stimulate and restore habitat in residential and commercial urban areas (NWF 2013). The quantitative value given to this garden lies in the range of possibilities, but hasn't been realised in any other assessed yard. The other outlier - yard number 294 - is also a highly diverse yard. It includes an edible design and many cultural yard-factors contributing to high diversity. Statistically, on the overall sample level and on the city level the values for these yards don't influence the mean much (also see Pallant 2005, p.62). At the neighbourhood level the two outliers explain some peculiarities in the data.

The descriptive statistics for the total sample level $(N=512)$ have been used to calculate the Total Diversity (TD) score bar that represents possible score levels for the contribution and discontribution to biodiversity delivered by the gardens (see Table 3 and Fig. 2). The score bar shows a minimum contribution to diversity of -5 (causing damage) to a maximum contribution to diversity of 47 (very high contribution to diversity) - based on a median of 15 (close to a mean of 15.6) and a standard deviation of 8.9.

Points leading to the TD score were distributed by analysing the photos using the BIMBY indicator set (see Appendix 2 and Beumer and Martens (2015)). Firstly, the way the individual yards fit to the climatological zone was defined by contextually comparing the habitat type to the regional climate (e.g. xeric or mesic). This resulted into a Regional Biome Match point (1 point for match and 0 points for no-match). ${ }^{2}$ Secondly, the value for the amount of green coverage, the type of soil cover other than green, and the permeability were added. Next the points were distributed for plant abundance, plant richness, and the vertical diversity of the individual yards (Hart 2007; Beumer and Martens 2015). Finally points were distributed for anthropogenic contribution factors and points were deduced for disturbance factors (see Appendix 2 for the weights given to the variables) (Beumer and Martens 2015). The TD

\footnotetext{
${ }^{1}$ When talking about the 'city level' the four neighborhoods in each city are meant. In accordance with this the samples are not representative for the state of the entire cities. The results only say something about the assessed neighbourhoods.

${ }^{2}$ In the analyses, xeric can also mean that the soil is bare or the coverage is composed of pavement. This means the way the term 'xeric' is used can be in contrast with the native desert landscaping style called 'xeriscaping' in the Phoenix area.
} 


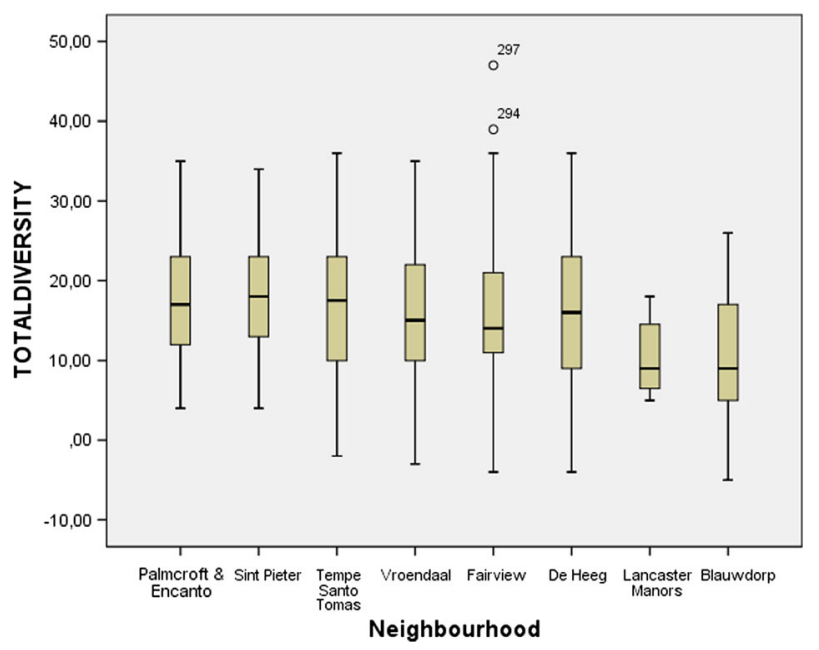

Fig. 1 Range of TD for each neighbourhood

score delivers an indication of the socio-cultural-ecological contribution or dis-contribution of the front-yards to biodiversity on the neighbourhood and the city level. Together with the sensory observations and the contextual knowledge of the assessed area, the outcomes were linked to sustainability and ecosystem services delivered on the neighbourhood level in a qualitative way.

\section{Limitations}

The intention of the BIMBY framework is to contribute to an integrated socio-culturalecological understanding of domestic urban space and how it is constituted by an interaction of natural and human factors. A further intention is to enhance societal dialogue on

Table 3 Descriptive statistics Total Diversity on total sample level $N=512$

\begin{tabular}{|c|c|c|c|}
\hline & & Statistic & St. Error \\
\hline Mean & & 15.5801 & 0.39378 \\
\hline \multirow[t]{2}{*}{$95 \%$ confidence interval for mean } & Lower bound & 14.8065 & \\
\hline & Upper bound & 16.3537 & \\
\hline $5 \%$ trimmed mean & & 15.6050 & \\
\hline Median & & 15.0000 & \\
\hline Variance & & 79.391 & \\
\hline Std. deviation & & 8.91015 & \\
\hline Minimum & & -5.00 & \\
\hline Maximum & & 47.00 & \\
\hline Range & & 52 & \\
\hline Interquartile range & & 12.00 & \\
\hline Skewness & & 0.69 & 0.108 \\
\hline Kurtosis & & -0.150 & 0.215 \\
\hline
\end{tabular}




\begin{tabular}{|c|c|c|c|c|c|c|}
\hline-5 & -9 & 10 & 11 & 21 & 31 & $47>$ \\
\hline Damage & Discontribution & Low & Average & Modest & High & Very High \\
\hline
\end{tabular}

Fig. 2 Total Diversity score bar: levels of contribution or dis-contribution to biodiversity

biodiversity, ecosystem services and sustainability. The pilot assessment presented in this paper has been able to contribute to the first aim to a great extent as many valuable results were fostered. Some important indicators (i.e. animal species, fertilizer use, irrigation, tilling, damages, pests, and diseases) however, were hard to measure without consulting the residents. There were restraints that prevented an immediate response to this limitation. Therefore, we were not able to include all the indicators of the BIMBY framework in this pilot study. ${ }^{3}$ For meeting al aims of the framework in future research, it will be necessary to conduct interviews with the residents and to involve them into the assessments of their own gardens. Such a direct involvement will help garden owners see their yards with different eyes and it will stimulate a dialogue about the contribution of residential gardens to biodiversity, sustainability and ecosystem services (Beumer 2014; Beumer and Martens 2015).

\section{Results}

Table 4 presents the TD scores of Maastricht and Phoenix. Maastricht (32\%) scores higher on the dis-contribution level (Total Dis) compared to Phoenix $(23.3 \%)$. In the contributing categories (Total Con) Phoenix (76.6 \%) scores higher compared to Maastricht (68\%). Overall, Phoenix can be said to contribute more to TD compared to Maastricht. A significant percentage of $28.9 \%$ of the total sample can be considered as 'lost urban space' for biodiversity and ecosystem services (Table 5).

Comparing the medians on the neighbourhood level (see Fig. 1) reveals that there are also relevant differences in the TD scores across the neighbourhoods. With a median of 18 for example, Maastricht High turns out to be the most contributing neighbourhood of the sample, followed by Phoenix Mid-Range with a median of 17.5. The scores of these neighbourhoods fall within the higher side of the average contribution category. Phoenix Low and Maastricht Low score a median of 9.0 both, which can be depicted as a low contribution to diversity. Except from these neighbourhoods all the assessed neighbourhoods can be said to contribute to diversity averagely. The median from Phoenix Average (14.0) differs from the mean (17.1) significantly. This can be attributed to the two outliers in this neighbourhood that influence the mean (see Fig. 1).

\section{Regional biome match}

Matching the front-yard soil coverage with the regional biome, both cities show just a slightly larger amount of matching yards compared to mismatching ones: Phoenix $56.5 \%$ of matching xeric yards; Maastricht $52.7 \%$ of matching mesic yards. Maastricht High scores best with a mesic match score of $75 \%$. Phoenix Mid-Range displays the highest match to the arid Arizona biome with almost $93 \%$. Phoenix High and Maastricht Low have a large biome mismatch. In Phoenix High $75 \%$ of the yards have a mesic character contradicting the surrounding Sonoran desert environment. Maastricht Low shows a mismatch of $73.7 \%$, which means there is a high amount of xeric yards in this neighbourhood.

\footnotetext{
${ }^{3}$ The included indicators (see Appendix 2) are shades whereas the ones we were not able to include are white.
} 
Table 4 Contribution levels of Phoenix and Maastricht to Total Diversity (TD)

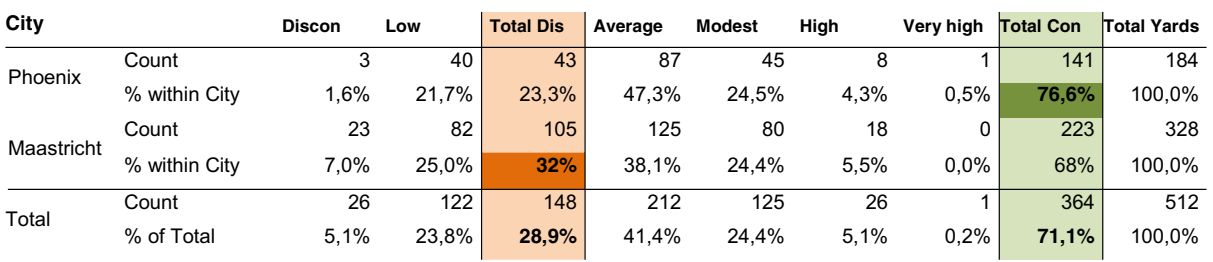

The orange column (Total Dis) represents the total points for discontribution (negative contribution) of the gardens to biodiversity, sustainability and ecosystem services. The green column (Total Con) represents the total points for positive contribution to biodiversity, sustainability and ecosystem services. The bold numbers inside the highlighted green and orange section indicate the highest level of respective contribution and discontribution

\section{Soil cover}

Lawns The assessed neighbourhoods in Phoenix have relatively many yards with the highest amount of lawn (37\%) compared to Maastricht (11\%) (see Table 6). Most of them are located in Phoenix High (65.9\%). Phoenix Mid-Range is contrasting this trend with only $5.4 \%$ of the yards covered with lawn for 50 to $100 \%$ and $91.1 \%$ of yards with no lawn coverage at all.

Table 5 Contribution levels on the neighbour hood level to Total Diversity (TD)

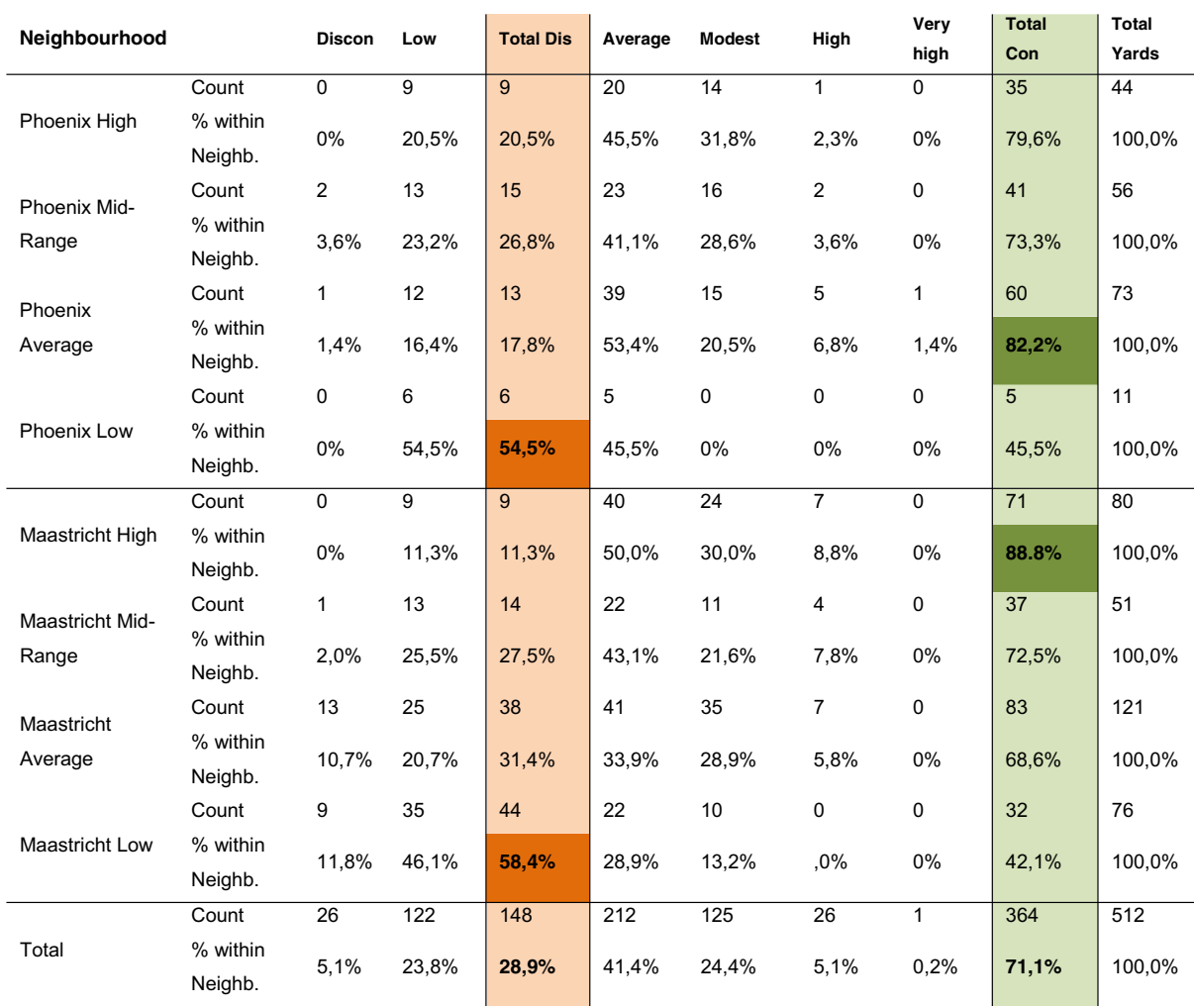

The orange column (Total Dis) represents the total points for discontribution (negative contribution) of the gardens to biodiversity, sustainability and ecosystem services. The green column (Total Con) represents the total points for positive contribution to biodiversity, sustainability and ecosystem services. The bold numbers inside the highlighted green and orange section indicate the highest level of respective contribution and discontribution 
Table 6 Soil coverage categories in Phoenix and Maastricht

\begin{tabular}{|c|c|c|c|c|c|c|c|}
\hline \multicolumn{8}{|c|}{ City * Lawn } \\
\hline & & & No & $<10 \%$ & $10-50 \%$ & $50-100 \%$ & \\
\hline \multirow[t]{4}{*}{ City } & Phoenix & Count & 94 & 1 & 21 & 68 & 184 \\
\hline & & $\%$ within city & $51.1 \%$ & $0.5 \%$ & $11.4 \%$ & $37.0 \%$ & $100.0 \%$ \\
\hline & Maastricht & Count & 270 & 0 & 22 & 36 & 328 \\
\hline & & $\%$ within city & $82.3 \%$ & $0.0 \%$ & $6.7 \%$ & $11.0 \%$ & $100.0 \%$ \\
\hline \multirow[t]{2}{*}{ Total } & & Count & 364 & 1 & 43 & 104 & 512 \\
\hline & & $\%$ within city & $71.1 \%$ & $0.2 \%$ & $8.4 \%$ & $20.3 \%$ & $100.0 \%$ \\
\hline \multicolumn{8}{|c|}{ City * Gravel } \\
\hline \multirow[t]{4}{*}{ City } & Phoenix & Count & 107 & 12 & 30 & 35 & 184 \\
\hline & & $\%$ within city & $58.2 \%$ & $6.5 \%$ & $16.3 \%$ & $19.0 \%$ & $100.0 \%$ \\
\hline & Maastricht & Count & 237 & 15 & 33 & 43 & 328 \\
\hline & & $\%$ within city & $72.3 \%$ & $4.6 \%$ & $10.1 \%$ & $13.1 \%$ & $100.0 \%$ \\
\hline \multirow[t]{2}{*}{ Total } & & Count & 344 & 27 & 63 & 78 & 512 \\
\hline & & $\%$ within city & $67.2 \%$ & $5.3 \%$ & $12.3 \%$ & $15.2 \%$ & $100.0 \%$ \\
\hline \multicolumn{8}{|c|}{ City * Pavement } \\
\hline \multirow[t]{4}{*}{ City } & Phoenix & Count & 116 & 41 & 18 & 9 & 184 \\
\hline & & $\%$ within city & $63.0 \%$ & $22.3 \%$ & $9.8 \%$ & $4.9 \%$ & $100.0 \%$ \\
\hline & Maastricht & Count & 97 & 78 & 55 & 98 & 328 \\
\hline & & $\%$ within city & $29.6 \%$ & $23.8 \%$ & $16.8 \%$ & $29.9 \%$ & $100.0 \%$ \\
\hline \multirow[t]{2}{*}{ Total } & & Count & 213 & 119 & 73 & 107 & 512 \\
\hline & & $\%$ within city & $41.6 \%$ & $23.2 \%$ & $14.3 \%$ & $20.9 \%$ & $100.0 \%$ \\
\hline \multicolumn{8}{|c|}{ City * BareSoil } \\
\hline \multirow[t]{4}{*}{ City } & Phoenix & Count & 126 & 13 & 27 & 18 & 184 \\
\hline & & $\%$ within city & $68.5 \%$ & $7.1 \%$ & $14.7 \%$ & $9.8 \%$ & $100.0 \%$ \\
\hline & Maastricht & Count & 286 & 15 & 22 & 5 & 328 \\
\hline & & $\%$ within city & $87.2 \%$ & $4.6 \%$ & $6.7 \%$ & $1.5 \%$ & $100.0 \%$ \\
\hline \multirow[t]{2}{*}{ Total } & & Count & 412 & 28 & 49 & 23 & 512 \\
\hline & & $\%$ within city & $80.5 \%$ & $5.5 \%$ & $9.6 \%$ & $4.5 \%$ & $100.0 \%$ \\
\hline \multicolumn{8}{|c|}{ City * Summary greencoverpoints } \\
\hline \multirow[t]{4}{*}{ City } & Phoenix & Count & 23 & 78 & 62 & 21 & 184 \\
\hline & & $\%$ within city & $12.5 \%$ & $42.4 \%$ & $33.7 \%$ & $11.4 \%$ & $100.0 \%$ \\
\hline & Maastricht & Count & 80 & 89 & 78 & 81 & 328 \\
\hline & & $\%$ within city & $24.4 \%$ & $27.1 \%$ & $23.8 \%$ & $24.7 \%$ & $100.0 \%$ \\
\hline \multirow[t]{2}{*}{ Total } & & Count & 103 & 167 & 140 & 102 & 512 \\
\hline & & $\%$ within city & $20.1 \%$ & $32.6 \%$ & $27.3 \%$ & $19.9 \%$ & $100.0 \%$ \\
\hline
\end{tabular}

Phoenix High, Maastricht High and Phoenix Average have a substantial amount of yards combining lawn with a significant amount of other soil covering elements.

Gravel The majority of the assessed yards in both cities have no gravel coverage at all (67.2\%) (see Table 6). Phoenix Mid-Range scores highest gravel coverage (41.1\% of the yards). This means that the low amount of lawns in there is compensated by the relatively high amount of gravel yards, which explains the xeric character of this neighbourhood. 
Pavement Comparing Maastricht to Phoenix shows there is a large difference between the amounts of paved yards in the two cities: The highly paved yards Phoenix and Maastricht differ significantly (see Table 6). Phoenix has only $4.9 \%$ of its yards paved between $50 \%$ and $100 \%$; Maastricht has a high pavement score of $29.9 \%$. On the neighbourhood level Maastricht Low (51.3\%) and Maastricht Average (32.2\%) score highest for pavement. Phoenix Low has the highest amount of yards with no pavement (81.8\%). The other neighbourhoods in Phoenix also have a majority of front-yards with no pavement at all. Phoenix Mid-Range contributes with $14.3 \%$ most to the yards with 50 to $100 \%$ pavement in Phoenix. Front yards there are occasionally used as parking space, sometimes adorned with plantation-strips at the edges.

Bare soil Both cities do not have a high amount of bare soil. This is indicated by the high scores for the 'no bare soil' category (see Table 6). Only Phoenix Low has a fair amount of yards $(36.4 \%$ ) with a 50 to $100 \%$ bare soil structure. In Phoenix, bare soil often indicates negligence and often leads to dusty circumstances, degrading the soil even more. Contrarily, in Maastricht bare soil often indicates the elimination of weeds by a higher care level.

Green cover In Phoenix only $11.4 \%$ of the yards are highly abundant with green coverage other than lawn. This is especially apparent in Phoenix High (40.9 \%) and Phoenix Mid-Range $(51.8 \%)$ in the less than $10 \%$ green coverage category. The highest amount of yards with no green coverage can be found in Maastricht Low (39.5\%), Phoenix Low (36.4\%) and Maastricht Average (25.6\%). This corresponds to the high pavement levels in the Maastricht neighbourhoods and the high bare soil percentage in Phoenix Low (see above).

\section{Abundance, richness and vertical diversity}

The plant diversity values have been composed of the combination of the points given for green coverage (see above), the abundance of perennials and annuals, on the richness of native and exotic species and on the presence of vertical diversity (Hart 2007; Beumer and Martens 2015). The calculation resulted into values ranging from 0 to 31. Based on a statistical assessment of normality we labelled the values as in Fig. 3.

Most of the assessed yards of the total sample are in the average category (61.9\%). Maastricht has with $33.5 \%$ significantly more yards with low plant diversity compared to Phoenix (21.7\%). Both cities score almost equal in the high diversity category (Phoenix $8.7 \%$ and Maastricht $8.5 \%$ ). Only Phoenix has one yard in the extraordinary category (one of the outliers). At the neighbourhood level Phoenix Low (54.5\%) and Maastricht Low (56.6 \%) in have least plant diversity. Phoenix Average turns out to be the neighbourhood with the highest amount of averagely diverse yards (76.6) together with Maastricht High (71.3\%). In the category high diversity Phoenix High scores best with $15.9 \%$ (often with exotics and annuals).

Another important indicator for biodiversity is the vertical diversity. This was measured by looking at the availability of flowers, shrubs, trees and weeds. One point was added up for the presence of each of these elements. This resulted in 'Vertical Points' (see Table 7). On the city

\begin{tabular}{|cc|cc|lc|lc|}
\hline 0 & 10 & 11 & 20 & 21 & $\begin{array}{c}30 \\
\text { High }\end{array}$ & 31 & $\begin{array}{c}40 \\
\text { Low }\end{array}$
\end{tabular}

Fig. 3 Scale of plant diversity 
Table 7 Vertical diversity in Phoenix and Maastricht

\begin{tabular}{|c|c|c|c|c|c|c|c|c|}
\hline & & & \multicolumn{5}{|c|}{ Vertical points } & \multirow[t]{2}{*}{ Total } \\
\hline & & & 0.00 & 1.00 & 2.00 & 3.00 & 4.00 & \\
\hline \multirow[t]{4}{*}{ City } & Phoenix & Count & 6 & 21 & 42 & 71 & 44 & 184 \\
\hline & & $\%$ within city & $3.3 \%$ & $11.4 \%$ & $22.8 \%$ & $38.6 \%$ & $23.9 \%$ & $100.0 \%$ \\
\hline & Maastricht & Count & 26 & 72 & 104 & 80 & 46 & 328 \\
\hline & & $\%$ within city & $7.9 \%$ & $22.0 \%$ & $31.7 \%$ & $24.4 \%$ & $14.0 \%$ & $100.0 \%$ \\
\hline \multirow[t]{2}{*}{ Total } & & Count & 32 & 93 & 146 & 151 & 90 & 512 \\
\hline & & $\%$ within city & $6.3 \%$ & $18.2 \%$ & $28.5 \%$ & $29.5 \%$ & $17.6 \%$ & $100.0 \%$ \\
\hline
\end{tabular}

level Phoenix scores highest in the categories of high vertical diversity: three (38.6\%) or four $(23.9 \%)$ points. In the case of four points it means that all the vertical features are available. Overall, most yards of the total sample score highest in the categories where two or three points are distributed (respectively 28.5 and $29.5 \%$ ). Only a small amount of yards, but still a significant $6.3 \%$ present none of the features adding to vertical diversity.

On the neighbourhood level Phoenix Average (30.1\%), Phoenix High (30.4\%) and Maastricht High (27.5\%) score best in the category where four points are given for vertical diversity. Maastricht Low (1.3 \%) and Phoenix High (6.8 \%) score least in this category. However, Phoenix High scores extremely high in the category for three vertical diversity points $(61.4 \%)$, including everything except for native wild plants or 'weeds'.

Trees need some special mentioning in the context of vertical diversity: they are best represented in Phoenix High where $90.9 \%$ of all the yards have one or more private trees. Maastricht Average (33.1\%) and Maastricht Low (13.2\%) score lowest in private trees. However, this doesn't mean that these neighbourhoods are devoid of trees. In these neighbourhoods trees are integrated in the urban planning design, which can also be said for most of the other visited neighbourhoods, except for Phoenix Low and Phoenix Mid-Range. In these latter neighbourhoods low level of private trees are combined with the absence of municipal trees.

\section{Anthropogenic factors}

Using anthropogenic factors as indicators for biodiversity (as contributors or disturbers) isn't very common. Here we demonstrate that including anthropogenic variables reveals interesting patterns. For each occurring anthropogenic feature one point was distributed. In total not more than eight points were given to an individual yard. This point only occurred in the permaculture yard in Phoenix Average.

\section{Contributors}

Although Maastricht Low scores rather low in the biotic contributions to biodiversity and high in the zero-category of a-biotic contributions, it has the highest amount of public and private bird-nesting opportunities. Coloured nest-boxes are on many of the street trees and home walls in this neighbourhood (13.2\%). A social-housing company of the neighbourhood carried out a project where these nest-boxes were made by artists with children and patients of a psychiatric 
care facility (Woonpunt 2012). A common garden in the neighbourhood would have added another large amount of nest-boxing facilities to this neighbourhood. Maastricht Average follows Maastricht Low in the lead on nest-boxes with $5.8 \%$. Nevertheless, these percentages are low. Insect-hotels weren't present in any of the visited yards. Phoenix High takes the lead with bird-feeders (13.6\%), closely followed by Phoenix Average (12.3\%). Most of them are intended for hummingbirds. Possibly, it can be attributed to the visiting season (spring and early summer), but wild food was also low in most of the neighbourhoods. Phoenix Average had most available wild-food (17.8 \%). This can be related to the presence of the two edible yards there. Bird-bathing facilities were hardly available anywhere. Phoenix High had the most of these facilities with only $6.8 \%$. Most of the baths were not filled with water though. Phoenix High (52.3 \%) and Phoenix Average (49.3\%) present the highest amount of plantcontainers. These can be tiny 'micro-climates' with other soil temperatures, structures and moisture levels than surrounding yard-features. They can be favourable nesting places for insects like carpenter bees. Also, very often the containers are used to house exotic plant species that are potentially attractive to native animal species as well (Burghardt et al. 2008; Kirmer and Tischew 2010; Heezik et al. 2012). Compost and other organic matter can hardly be found in any of the front-yards in the visited neighbourhoods. Visible irrigation systems show a significantly higher abundance in Phoenix yards $(28.3 \%)$ compared to Maastricht (1.2\%). Especially Phoenix Average with $38.4 \%$ and Phoenix High with $31.8 \%$ have many yards with visible irrigation systems. Based on the sensory information, the use of irrigation seems to be higher in Phoenix High compared to Phoenix Average.

\section{Disturbances}

With regards to potential disturbances, artificial light scores high in Phoenix, with Phoenix High in the lead: $52.3 \%$. Phoenix Mid-Range scores also high with $48.2 \%$, followed by Phoenix Average (34.2\%). The Dutch neighbourhoods have significantly less light installations, ranging from zero in Maastricht High to $3.3 \%$ in Maastricht Average. Artificial light has often been qualified as a disturbance for urban wild animals (Stone et al. 2012; Lewanzik and Voigt 2014; Perkin et al. 2014). However, other research indicates that some spiders species fare well by these features as light attracts their food sources (Lowe et al. 2014). Many frontyards have benches or tables installed to facilitate social time in the yards. In Phoenix Low (45.5\%), Phoenix Average (35.6\%), Phoenix High (25\%) most furniture can be found. Maastricht Mid-Range (5.9\%) and Phoenix Mid-Range (5.4\%) have least furniture. The most frequently observed disturbance after the light installations and furniture is the habit of people to park vehicles like bicycles, motorbikes, baby-buggies and cars in their front-yard. Overall, the yards in Maastricht are more often used for parking vehicles than the ones in Phoenix. This can be attributed to the many bicycles that are given a parking-spot in Dutch yards.

\section{Design style}

Design styles can be indicative for the way yards contribute to biodiversity and ecosystem services or disservices (Orians 1980; Schulz 1985; Lohr 2007; Chou et al. 2011). Although there are globally many more styles, we only included the ones that were meaningfully identified during the field visits and photo analyses (see Fig. 4).

At the city level desert gardens (xeriscape) (Norris-Bernzel and Edinger 2005; Larsen and Harlan 2006) are most popular in Phoenix. These account for $26 \%$ of all the analysed yards in 


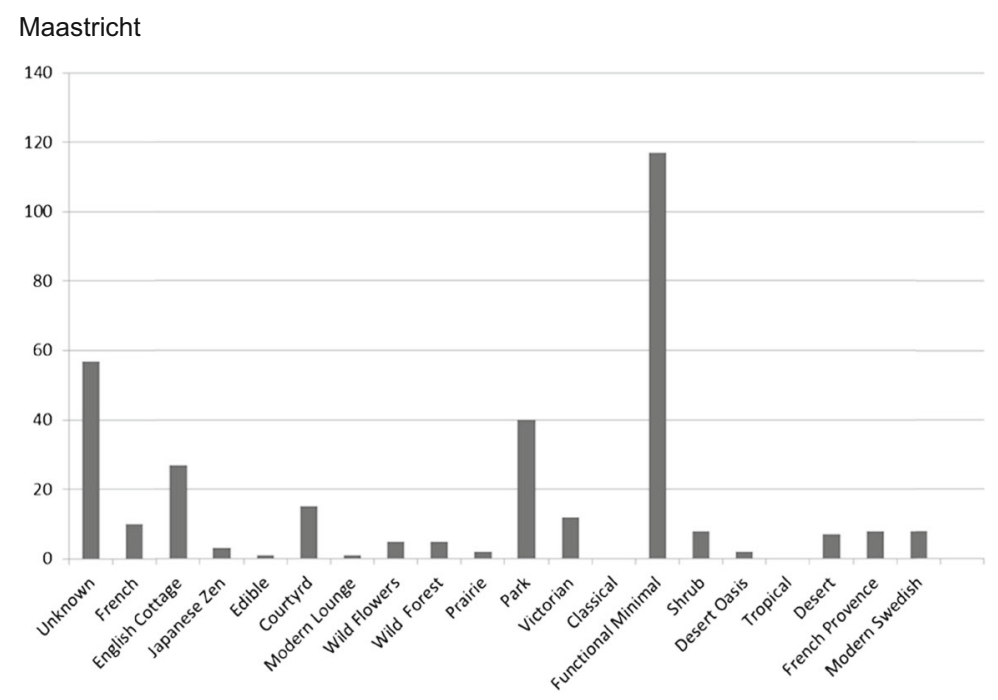

Phoenix

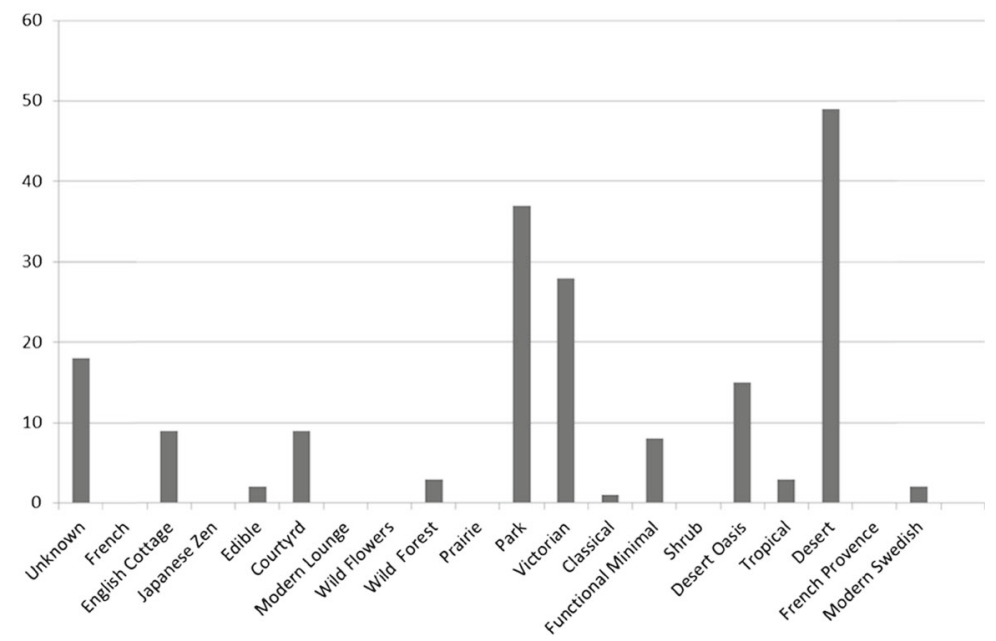

The $y$-axis indicates the number of gardens representing a certain design style.

Fig. 4 Design inspiration in Phoenix and Maastricht

Phoenix. However, the green English style picturesque or 'park' gardens (20.1\%) (Szilagy 2011) and the gardenesque — or Victorian gardens (Ignatieva 2010) — both garden types with lawns, shrubs and trees (and in the Victorian gardens flower beds with usually exotic flowers) together make up for $35.3 \%$ of the yards in Phoenix. These gardens add biodiversity to the otherwise native desert environment, but bring along many sustainability problems like water shortages (Larsen and Harlan 2006; Martin 2008; Larson et al. 2009; St. Hilaire et al. 2010; Smetana and Crittenden 2014) and pollution through the higher use of pesticides and herbicides in lawns (Khachatryan and Zhou 2014; Smetana and Crittenden 2014). In Maastricht 'desert-gardening' is also popular. We called these yard-types 'functional minimalist' because 
they combine low maintenance needs with a low occurrence of any type of green and a high occurrence of pavement or gravel. Often these yards are used for parking vehicles or for equipped for social activities (BBQ and/or furniture). The more maintenance intensive version of this type of yard often reflects elements from $18^{\text {th }}$ century Régence Gardens with fantastic and intricate forms of topiary, referred to in the literature as 'Dutch Taste' (Hopper 1981). The functional minimalist yard occurs $35.7 \%$ of all the yards in Maastricht.

Each individual neighbourhood can be said to have a general most popular design that distinguishes it from the others. In Phoenix High the gardenesque $(45.5 \%)$ and picturesque (20.5\%) yards prevail. Phoenix Mid-Range is characterised by native desert (xeriscape) gardens (58.9 \%). Phoenix Average favours park-gardens most (30.1\%) and Phoenix Low also has prevalence for the picturesque park idea (54.5\%). In Maastricht High the most occurring yard types can be described as park (22.5\%) and cottage style (20\%). Maastricht Mid-Range has a high occurrence of park (33.3 \%) and functional minimalist (21.6\%) yards. Also a relatively high level of Versailles style gardens occurs (7.8\%), which is a style based on neatly kept geometric patterns and structures, most commonly combining (buxus) hedges with lavender, roses or hydrangea. Maastricht Average is characterized by a high level of functional minimalism (42.1\%). This is the same for Maastricht Low $(56.6 \%)$.

\section{Levels of intentional design}

The level of intentional design indicates how 'strictly' people apply structures and features (e.g. geometrically planted patterns, and fantastic forms of topiary, pavement-designs, swimming pools etc.) in their yards, complementary to giving yards space to some spontaneous 'wilder' plant growth. Overall most gardens are occurring in the category of high intentional design ( $45.7 \%$ of all the yards in our sample). The highest percentage of yards with high intentional designs occurs in Maastricht Mid-Range (72.5\%). This can be explained by the fact that this is a young neighbourhood (built in 2000) where design intentions are still very visible. Phoenix Low is the only neighbourhood where a low intentional design overrules medium or high intention. In Maastricht High a medium intentional design is most common, pointing towards the high occurrence of cottage style yards (20\%) in this neighbourhood that give some space to (seemingly) spontaneous growth. Also the relatively high 'allowance' for weeds (in $43.8 \%$ of the yards) contributes to this value in the neighbourhood.

\section{Care level and care need}

Some yards are designed to have low maintenance needs and some need high maintenance to fulfil their design. The level of care that is needed for individual design styles can differ depending on climate, e.g. rainfall and temperatures. A lawn in Phoenix needs much more care (e.g. irrigation, fertilizers) (Martin 2008) compared to a lawn in Maastricht. A garden full of wild flowers may seem care-intensive and time consuming to maintain, but in both regions, whilst native plants are considered in the design, this doesn't have to be the case. Comparing care levels and care needs also provides information on how engaged people are in the activity of gardening. The level of high maintenance yards in Phoenix (41.3\%) is much higher compared to Maastricht (14.6\%). This can be attributed to the high occurrence of park and gardenesque styles in Phoenix that - especially in a desert area - need a lot of care and work. In the medium maintenance need level Maastricht scores higher, whereas the low maintenance yards are almost equally distributed across the two cities. 
Interestingly, Phoenix Low has the highest percentage of yards with a high maintenance need design. Nevertheless the actual care level in this neighbourhood is very low (45.5\%), which results into an image of negligence. Phoenix Average (56.2\%) and Phoenix High $(50 \%)$ also have high percentages of high care needs in their yard designs. The actual level of care is higher in Phoenix High (79.5 \%) compared to Phoenix Average (46.6 \%). Maastricht Mid-Range has the highest need for care designs (27.5\%) in Maastricht. Least in this category scores Maastricht Low with only $2.6 \%$. Maastricht Mid-Range and Phoenix High have least yards with low actual care levels (respectively 7.8 and $4.5 \%$ ).

\section{Discussion}

\section{Ecosystem services and disservices: A qualitative evaluation of the results}

Based on biogeography, and Species Area Relationships (SARs), more biodiversity is usually considered to be better (Rosenzweig 2003; Whittaker and Fernandez-Palacios 2007). Halting the loss of biodiversity is crucial for sustaining the well-being of all inhabitants of the planet, but bringing it back to places where people once 'eliminated it' can also have adverse effects on human well-being and the environment (Lyytimäki et al. 2008). Nuisance, available time, health issues (pollen, pests, venomous plants, prickly plants, allergies etc.) and safety risks (dark parks, falling tree branches, aggressive wild animals etc.) related to gardening practices and designs should not be underestimated (Lyytimäki et al. 2008). In this discussion section we focus on the role of the socio-cultural-ecological garden features that contribute to biodiversity. The results described above are now placed in a context of sustainability (Newman 1999; Dresner 2002; Giddings et al. 2002; Banerjee 2003; Castro 2004; Robinson 2004; Williams and Millington 2004; Martens 2006; Rees and Wackernagel 2008; Rees 2010) and ecosystem services (Costanza et al. 1997; Opschoor 1998; Bolund and Hunhammar 1999; Lyytimäki et al. 2008; TEEB 2009, 2011; Ignatieva et al. 2011; Mitchell et al. 2013; Costanza et al. 2014). The most important services and disservices identified on the level of the neighbourhoods are described. This 'contextualisation' has been done qualitatively, taking into account the indicator-results, the sensory neighbourhood observations and the contextual knowledge - based on empirical experience and literature - of both regional environments. A schematic summary and systematic categorisation of the ecosystem services and dis-services of each neighbourhood can be found in Appendix 3.

\section{Phoenix}

In Phoenix there occurs a tension between neighbourhoods that contribute to biodiversity in relatively high levels_-like Phoenix High — while at the same time causing sustainability problems. Research done by others in the Phoenix area confirms these findings (Martin 2008). With the ideal of maintaining a once propagated image of Phoenix as an oasis in the desert (Larsen and Swanbrow 2006) many species that are brought into the city are contrasting the native desert environment. Phoenix High is a post WWII suburban neighbourhood for the wealthier, displaying a variety of historic architectural styles. There are Home Owners Associations (HOA) that urge residents to conform their gardens to the aesthetical standards of the historic area. The green in this neighbourhood is designed to be friendly to people: it gives people a 'break' from the harsh desert by providing a cooler, shady sub-climate through 
places with high evapotranspiration (Martin 2008), a regulating service. Phoenix High looks like a 'patchwork' of small green oases where one can almost forget to be in a desert. This green character adds higher levels of diversity to the whole Phoenix region (Martin 2008). However, lush and green gardens in a desert environment are time, fertilizer, costs- and water intensive (Zube et al. 1986; Nassauer 1995; Larsen and Harlan 2006). More than $70 \%$ of the household-water in Phoenix is spent on watering lawns like the ones prevailing in Phoenix High (Mee 2011).

Phoenix Mid-Range was built in the 1970's and has a rather uniform character of homes with patios, small front yards and adobe-walled gardens that give the neighbourhood architecture a Mexican flavour. It has a high amount of xeriscape yards (Norris-Bernzel and Edinger 2005; Mee 2011) although some green lawn yards can also be found here. With its relatively high vertical diversity and many native plants it potentially contributes to a functional connectivity to the desert (Rudd et al. 2002). The neighbourhood reflects an ideal of contributing to the local environment through the abundant planting of native species and water saving measures (Mee 2011). The relatively high maintenance level of these intentionally lower maintenance yards reflects a wealthy and neat neighbourhood image. The downsides of the front-yard designs can partly be found in the walled character. The adobe-walls provide shade on the streets and in the backyards. However, due to the plaster on most of the walls they don't provide habitat to small, insects or other animals and they mainly fragment the neighbourhood and decrease the structural connectivity (Rudd et al. 2002). Research pointed out that the environmental advantages of saving water in drought tolerant yards are undone by the heightened use of pesticides in such yards (Larson et al. 2010). Other research demonstrated that the dripping-systems that are installed in xeric yards often operate at higher frequencies than is actually necessary for the survival of the desert plant species (Martin 2008). The net benefits for urban resilience and sustainability are at least questionable.

Phoenix Average is a central Phoenix historic district built in the 1920's with various architectural styles (Fairview 2009). Most homes have front and backyards. The neighbourhood is flanked by a rose garden and the oasis-like Encanto Park on the East. Phoenix Average is characterized by a high diversity of yard design styles which contributes delivers many ecosystem services and increases biological diversity of the nearby environment. A significant number of yards theoretically contribute to the functional connectivity to the native desert (Rudd et al. 2002). Other yards contrast the desert with lush green abundance. There are two yards with edible designs based on the principles of permaculture (Mollison 1988; Hemenway 2009). One of these yards even contributes to biodiversity as a certified Wildlife Habitat (Rosenzweig 2003; NWF 2013). The yards with lawns and trees provide climate regulation: cooler micro-climates and higher well-being through evapotranspiration (Martin 2008). The neighbourhood also expresses an interest in social encounter by the many seating facilities in the front-yards, by art-works, and by the educational and inspirational character of the permaculture Wildlife Habitat. Disservices are especially caused by the neglected yards where soil erosion creates dust problems and little 'deserts within a desert'. These yards can also cause a drop in property value for the surrounding homes and create potential image problems for the block.

Phoenix Low is a deprived neighbourhood with small homes built in the 1940's and 1950's. It is located near Phoenix Sky Harbor Airport, the open air Pueblo Grande Museum and not too far away from the semi-wild urban desert Papago Park that houses the Desert Botanical Garden (DBG 2013). All homes in the area have front and backyards. The front-yards don't contribute much to biodiversity. However, there are some positive aspects related to 
sustainability here: the low level of care indicates that not much water is spent. Signs of social encounters are present through playing equipment and furniture in some of the yards. However, the visible lack of care results into diminished aesthetic qualities and property values and causes a potential feeling of unsafety. The prevalent bare soil structures and the lack of trees cause a strong heat island effect and dusty air. Research points out that residents living in deprived areas such as Phoenix Low generally have less access to green and lack the financial means to enrich their own yards with abundant life (DesJardins 2006; Hope et al. 2006; Martin 2008; Mitchell and Mueller 2009; Pearsall and Pierce 2010; Beatley 2011). A lack of experience of green can also feed back into the ongoing loss of biodiversity, considering the assumption that "people are most likely to take action for biodiversity if they have direct contact with nature (Müller et al. 2010, p.26)."

\section{Maastricht}

Compared to Phoenix, Maastricht has a high amount of xeric yards that create a barren urban landscape. Although people may consider such yards time- and money- efficient, they have many adverse effects: they contribute to landscape fragmentation and habitat loss; to soil and water degradation (through the use of herbicides); to an increased urban heat-island effect during hot summers; to decreased $\mathrm{CO} 2$ sequestration; and they may cause flooding-problems during strong rainfall due to the loss of soil permeability. Functional minimalist yards also lack the psychological and health benefits that are coupled to lush green environments (Kaplan 1995; Maas et al. 2006; Nasar 2011; Van den Berg et al. 2014).

The wealthy Maastricht High quarter seems most contradictive to the functional minimalist trend. Maastricht High used to be an independent village just outside the Maastricht inner-city walls and became part of the municipality in 1920. Natural areas connected to the neighbourhood are the Pietersberg and Jekerdal with the Jeker Creek. At the East side Sint Pieter is flanked by the river Meuse. At the north side the ring road around Maastricht separates the neighbourhood from the picturesque inner-city park. The homes are an eclectic assemblage of architecture from the early 20th century and the late 19th century. Also more recent and even modern architectural styles can be found. Through its relatively high diversity of yards the neighbourhood contributes comparably much to food and habitat for a diversity of animal species. The diversity and lush features and the open character of many yards make them nodes in a network of functional connectivity (Rudd et al. 2002). Cultural services are delivered by the aesthetic quality of the neighbourhood, contributing to well-being, sports and recreation in the adjacent natural parks. The high quality of life contributes to high property values and the neighbourhood being a very popular area for affluent residents and visitors. Potential harm to the local environment can be caused by the spreading of invasive alien species from the yards to proximate nature. The higher maintenance levels of many yards, especially the gardenesque ones and the yards with geometric Versailles designs, can cause disturbance to nesting, feeding or sheltering animal species. High maintenance levels also often imply regular soil disturbance (Hemenway 2009).

In the newly built Maastricht Mid-Range (2000) people may feel safe and sound. The neighbourhood is located at the edge of the historic forest Savelsbosch. Various real estate websites promote the neighbourhood as being 'close to nature.' Close to nature in this case means 'separated' from it as well: Maastricht Mid-Range is characterized by yard-types that form a contrast to the very proximate forest which is a home to badgers, foxes, dear, squirrels and an abundance of many other animal species. Many of the yards have hedges that 
potentially provide habitat, shelter, connectivity and nesting facilities for birds, hedgehogs and other species. However, they are usually well trimmed and pruned, which can cause disturbance, anxiety and the loss of habitat functions (Martin 2008). Soil health may be low or decreasing in this neighbourhood due to high maintenance-, lawns-, and pavement patterns. The maintenance of lawns and hedges potentially also causes nuisance for neighbours due to machine noise and fumes (Tint et al. 2012).

Maastricht Average is a neighbourhood with two faces: a green face and a grey face. The high amount of pavement and other soil covering structures creates 'desert patches' devoid of any life. At the other side, there is tolerance for individual expression and there are quite a number of yards with highly diversely planted designs. The municipal design of the neighbourhood is green and spacious with many trees, shrubs, grass patches and a picturesque style park meandering through the whole length of the area. The maintenance of the park by sheep grazing contributes to a higher diversity of wild flowers and grasses. The neighbourhood delivers many cultural services, such as garden-watching, children and dog-playing opportunities, watching and stroking the sheep, and picnic areas. Some yards are nodes in the functional and structural connectivity to the park and the nearby Savelsbos (Rudd et al. 2002). The municipal trees, shrubs and the flowered yards provide an abundance of habitat food for small animals like hedgehogs, pollinators and birds. The municipal design of the neighbourhood compensates for many potential disservices delivered by the high amount of paved yards: water-runoff; urban heat-island effect; loss of aesthetic value; loss of (social) well-being. However, the park also causes disservices reflected by residents: reduced feeling of safety due to abundant municipal hedges and a lack of illumination during the dark hours. Because of the lack of private 'ownership' of trees, there is a higher potential for experiencing nuisance related to falling leaves of the municipal trees.

Maastricht Low provides little benefits to biodiversity. The high level of pavement and gravel contribute to 'desertification' of the area. With the perspective of a changing climate and stronger peak rains and hotter summers ahead (Steffen et al. 2005; Simonis 2011; IPCC 2013), the high amount of paved gardens adds to higher municipal and health care costs due to physical and psychological discomfort, heat stress, water-runoff and flooding (Huynen et al. 2004; Alcoforado and Andrade 2008; Huynen 2008; Theeuwes et al. 2012; Rahola et al. 2014; Zwaagstra 2014). The grey-ness of the district does not contribute to a positive image and it reduces a feeling of comfort and safety. However, there is a high level of social use of the front-yards. This can be seen as a disturbance to wildlife but also as leading to higher social cohesion and neighbour contacts. Costs for people to maintain their yards are low, which is the same for the time they may spend on care and maintenance. There may be issues of environmental justice (Mitchell and Mueller 2009; Pearsall and Pierce 2010) due to a lack of resources and knowledge on facilitating a greener neighbourhood.

\section{Conclusion}

Through a pilot assessment of front-yards in Phoenix and Maastricht using the BIMBY indicator framework we were able to show how ecological, cultural and social factors like plantation, garden design, garden use, and maintenance levels relate to a contribution or dis-contribution to biodiversity, ecosystem services, urban and even regional sustainability. 
Comparing the two case cities showed that the assessed front-yards in Phoenix contribute to biodiversity more compared to the ones in Maastricht. Maastricht High turned out to be the most contributing neighbourhood, followed by Phoenix Mid-Range. The neighbourhoods with a socio-economical low status scored least for their contribution to biodiversity. Curiously, although the Average neighbourhoods in both cities did not score best in their contribution to biodiversity and sustainability, they showed the greatest diversity in their garden design, plantation, maintenance, and use styles on the neighbourhood level. Overall the neighbourhoods contributed to biodiversity in very different ways and styles that can be related to their history, dominant design, social conformation (i.e. the HOAs in Phoenix), and the socio-economic status of the neighbourhood.

It seems logical to assume that gardens that contribute to biodiversity in a stronger way also deliver more ecosystem services to people and contribute to urban and regional sustainability to a higher extent. In the case of Phoenix this logical assumption needs to be questioned at least. The high amount of green gardens adds diversity in the form of 'exotic' species and an 'oasis landscape' to the local and regional desert biome. However, these green park-like gardens consume more water than can be considered sustainable for the long-term existence of the city. This again needs to be traded off against the ecosystem services - especially cultural and regulatory services - delivered by the green gardens that provide the desert-city dwellers a more comfortable, less prickly, and cooler living environment. Such services are delivered only to a lesser extent by the xeric garden designs such as in Phoenix Mid-Range.

In Maastricht many gardens add to differentiation of the regional biome and the urban landscape. This can be attributed to the high individual freedom for home owners to design and maintain their yards. Many lush green gardens represent native and perennial vegetation and function as nodes in a green infrastructure that extends urban space. However, the highest amount of gardens in this city does not contribute to biodiversity and sustainability at all. This can be ascribed to the popularity of the functional minimalist garden. In Maastricht many residents seem to be guided by the choice for ease and time-efficiency when it comes to gardening and garden designs. The installation of pavement or fully gravelled yards results in the 'desertification' of an otherwise green eco-region. Here, a discussion could be started on whether this ideal of low-maintenance has to be covered by 'paved deserts'. Perhaps there are other options that combine time concerns, aesthetic concerns, and environmental concerns in the design. With the perspective of a changing climate (stronger peak rains and hotter summers) ahead, the high amount of paved gardens adds to an unsustainable and uncomfortable living environment that inevitably will lead to higher healthcare costs and repair costs of flooded homes and damaged infrastructures.

It can be concluded that a universal blueprint for a sustainable yard design does not exist. The contribution of domestic gardens to a sustainable living environment is highly dependent on the regional biome and on the social and cultural context. In order to better understand how gardening designs, preferences and maintenance styles in diverse sociocultural contexts contribute to biodiversity, the delivery of ecosystem services, and urban and regional sustainability, future research using the BIMBY indicator framework needs to include the experiences, observations and perspectives of garden owners. Active engagement of citizens will also lead to help building a societal dialogue on these issues, which is fundamental if we want to transform our cities into long-term thriving living environments. 
Acknowledgments Special thanks to the reviewers for their helpful comments, to Elisabeth Cook for the helpful feedback on this paper from an ecologist's perspective and great thanks to David Iwaniec and to Nancy Grimm for providing a home during the fieldwork in Phoenix.

Compliance with ethical standards The authors of this paper hereby declare to the journal Urban Ecosystems that we are in compliance with Ethical Standards with regards to the contents of the manuscript. In addition, there is no conflict of interests regarding the conduct of this research and we did not use humans or animals as test subjects while conducting the study.

\section{Appendix 1. Tests for normal distribution}

a. Total sample level

\begin{tabular}{lllllll} 
Tests of normality & \multicolumn{2}{l}{ Shapiro-Wilk } \\
& \multicolumn{3}{l}{ Kolmogorov-Smirnov } \\
& Statistic & df & Sig. & Statistic & df & Sig. \\
Total diversity & 0.049 & 513 & 0.004 & 0.993 & 513 & 0.013 \\
\hline
\end{tabular}

\section{${ }^{a}$ Lilliefors Significance Correction}
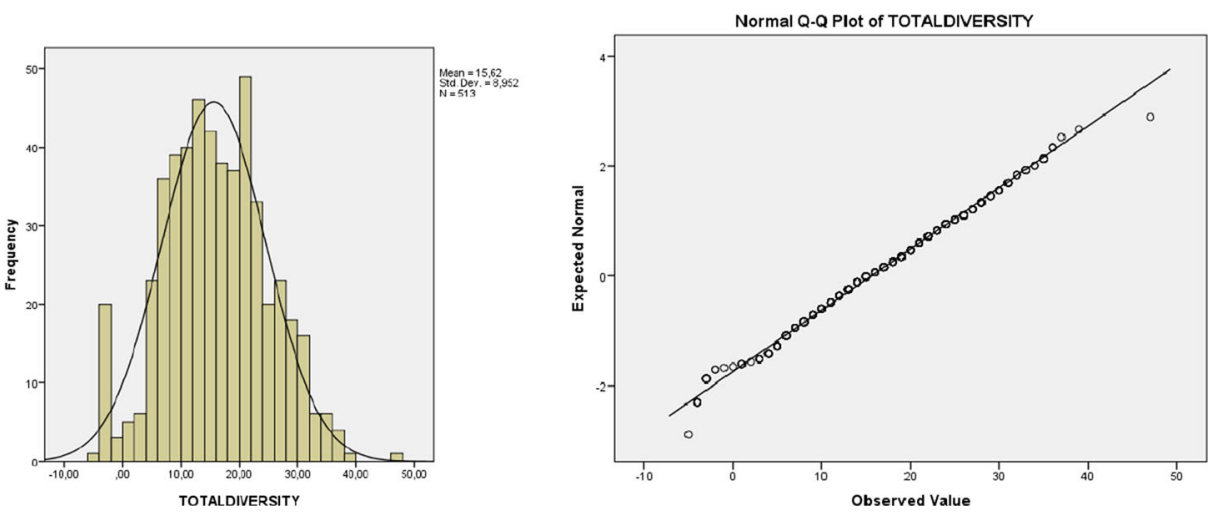

b. City Level

\begin{tabular}{|c|c|c|c|c|c|c|c|}
\hline \multicolumn{8}{|c|}{ Tests of Normality } \\
\hline & \multirow[t]{2}{*}{ City } & \multicolumn{3}{|c|}{ Kolmogorov-Smirnov ${ }^{\mathrm{a}}$} & \multicolumn{3}{|c|}{ Shapiro-Wilk } \\
\hline & & Statistic & $\mathrm{df}$ & Sig. & Statistic & $\mathrm{df}$ & Sig. \\
\hline \multirow[t]{2}{*}{ Total diversity } & Phoenix & 0.068 & 184 & 0.036 & 0.985 & 184 & 0.048 \\
\hline & Maastricht & 0.047 & 328 & 0.084 & 0.987 & 328 & 0.004 \\
\hline
\end{tabular}

${ }^{\mathrm{a} L i l l i e f o r s ~ S i g n i f i c a n c e ~ C o r r e c t i o n ~}$ 
c. Neighborhood level
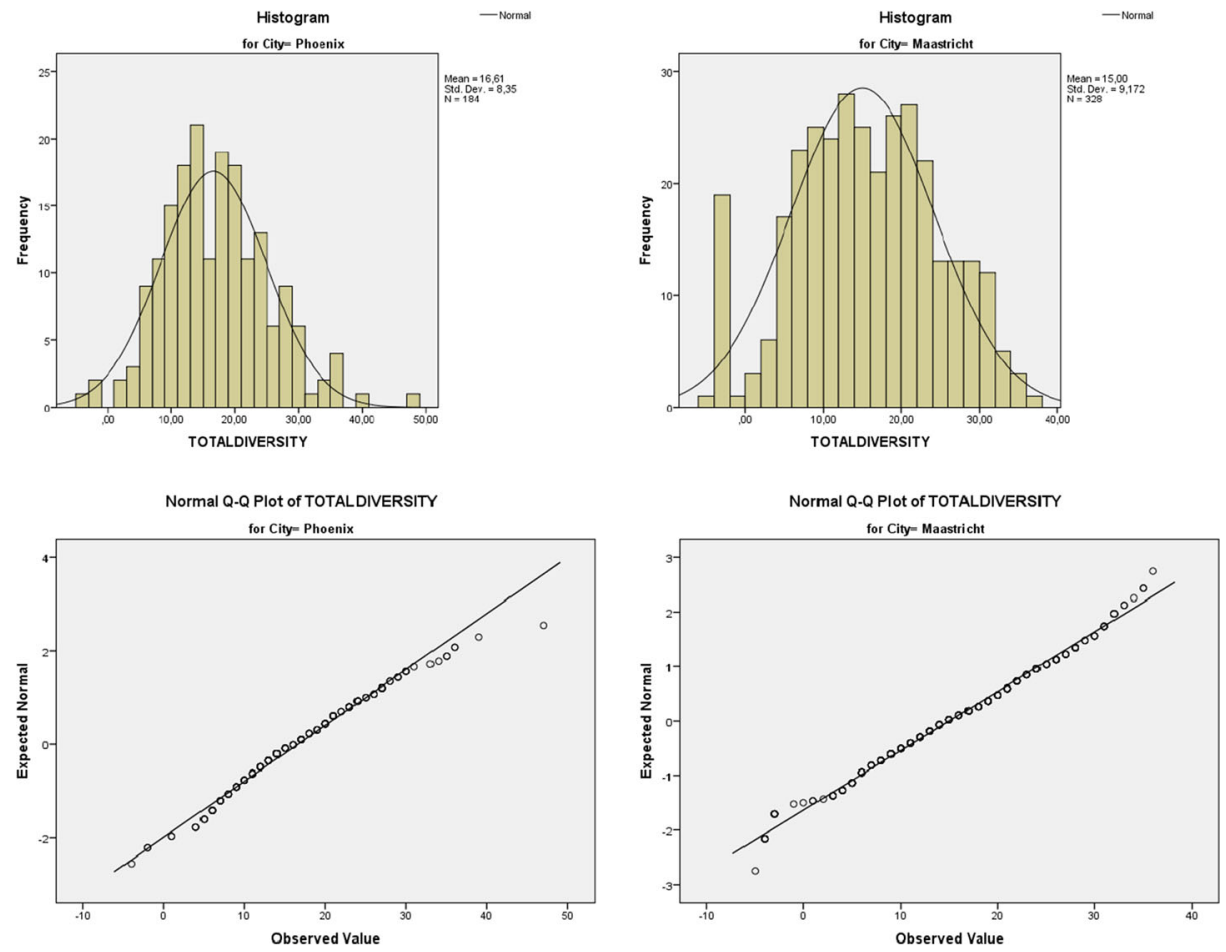


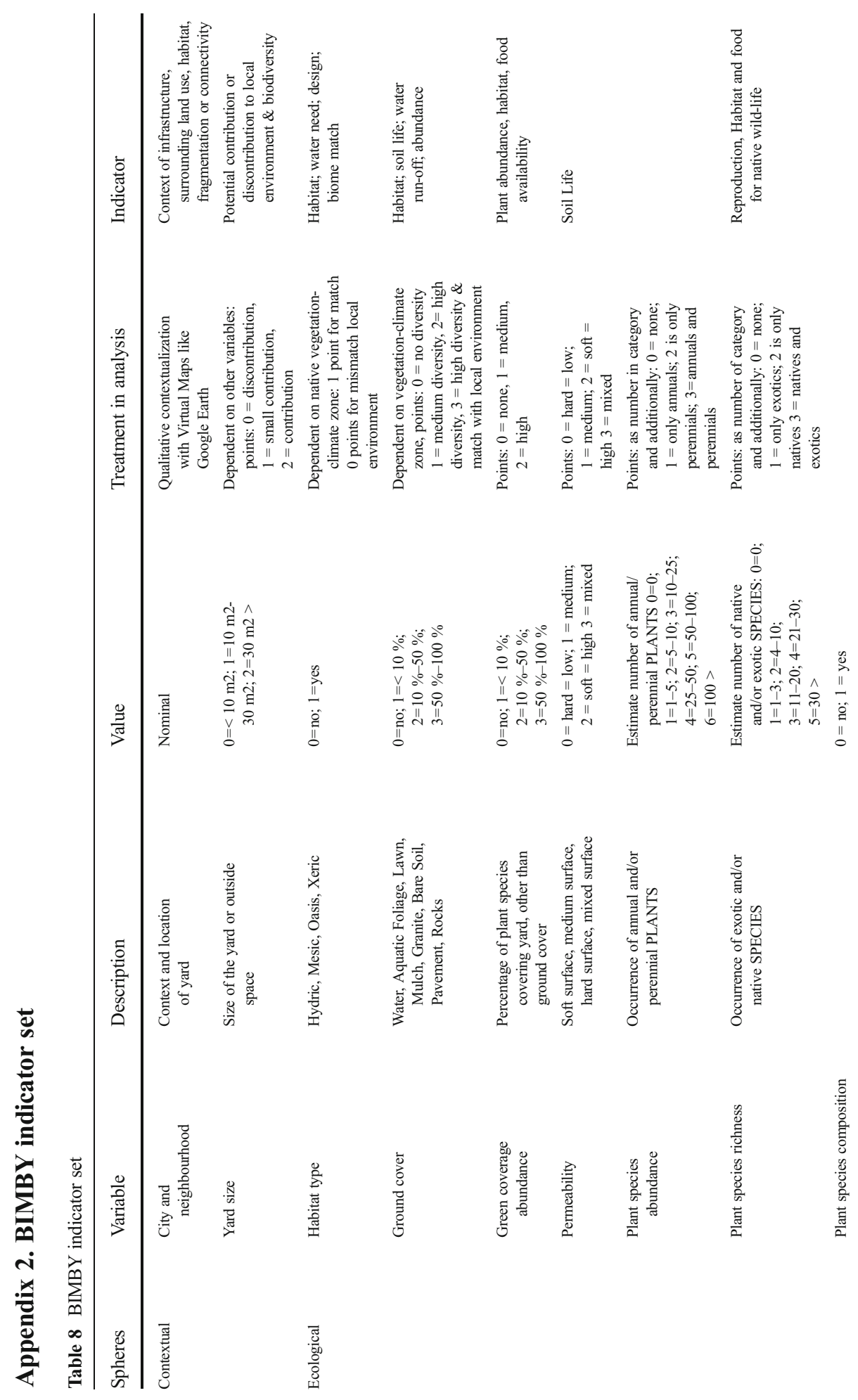




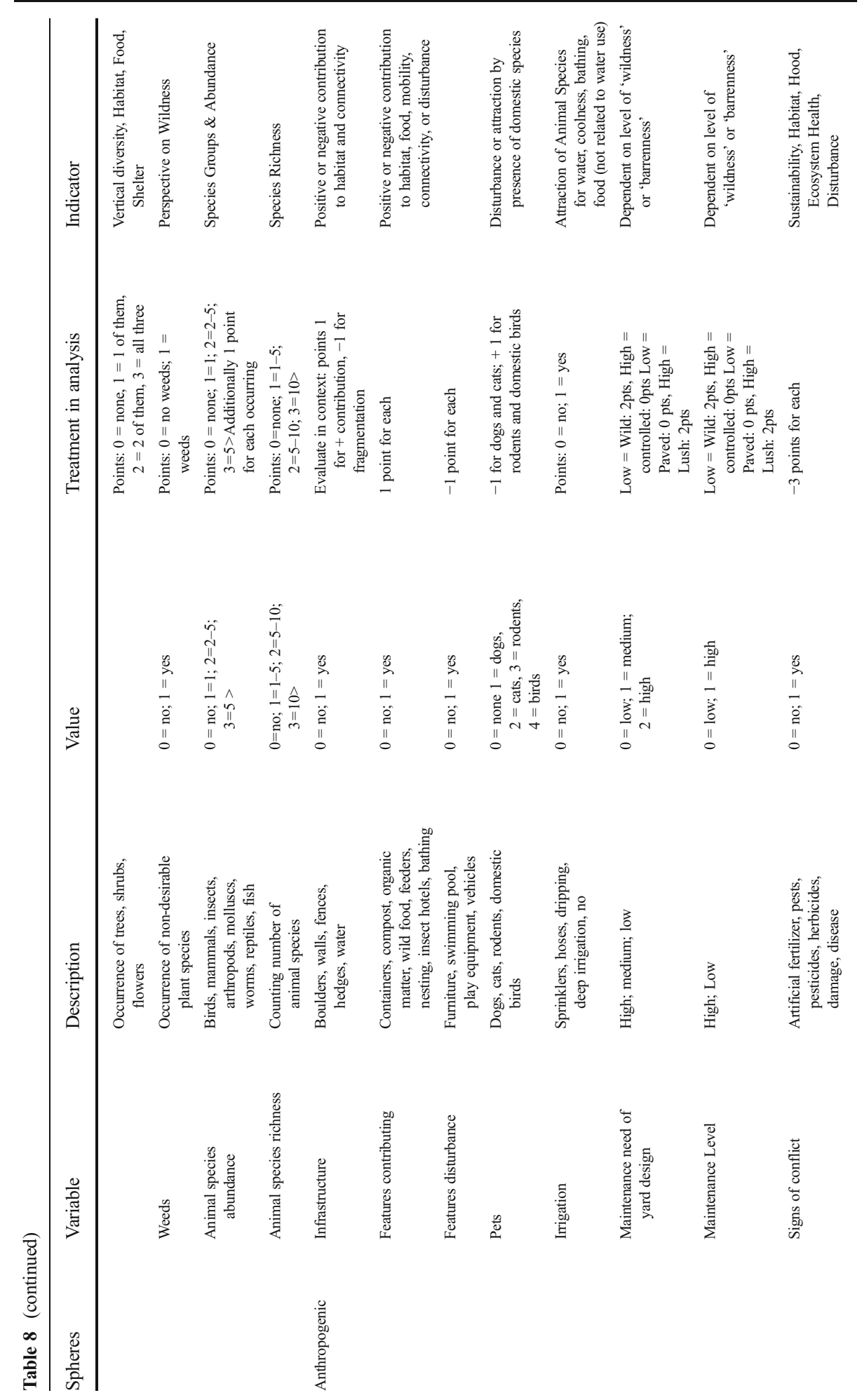




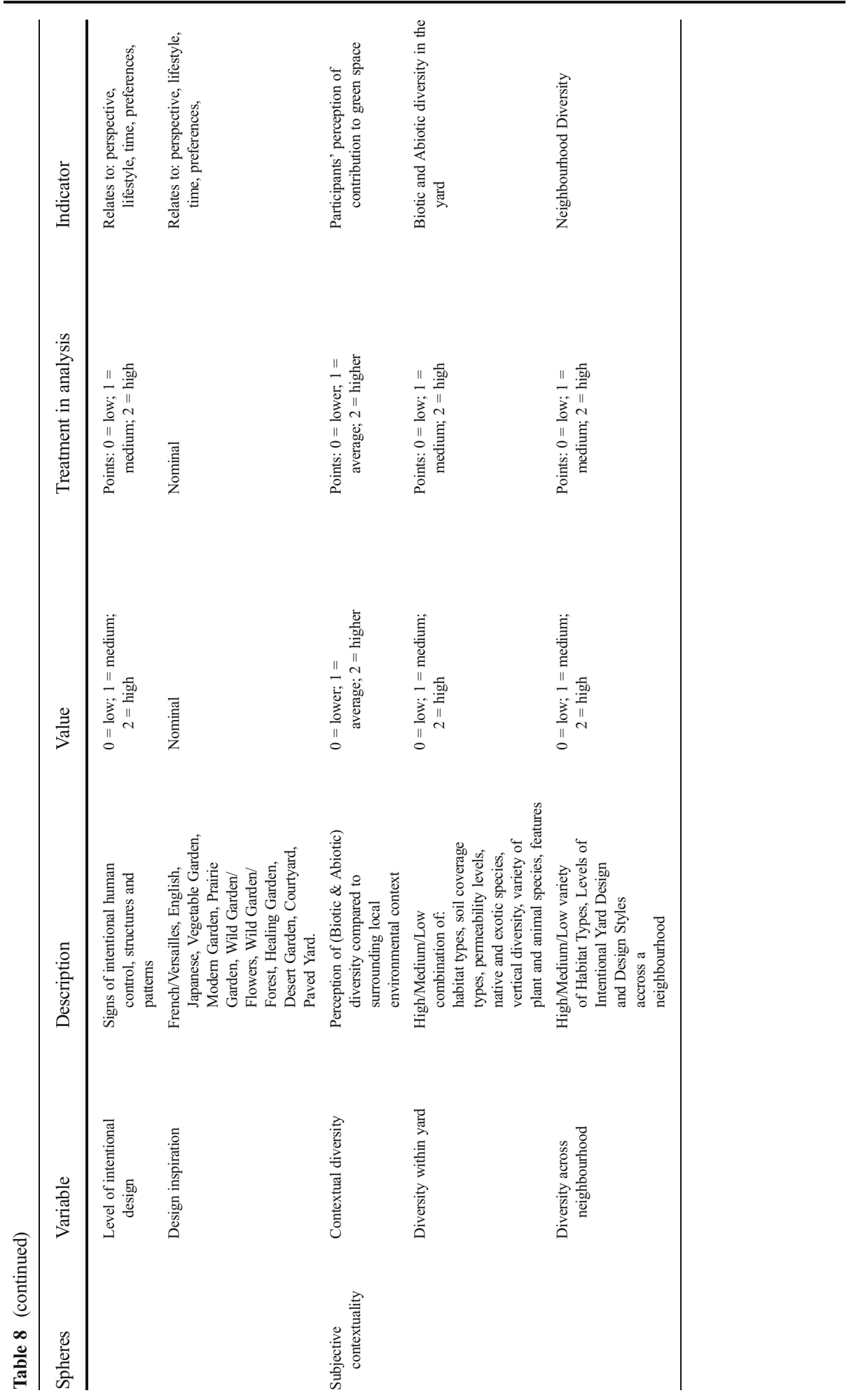


Appendix 3. Ecosystem services and dis-services on the neighbourhood level

\begin{tabular}{|c|c|c|c|c|}
\hline $\begin{array}{r}\text { Ecosystem } \\
\text { Services }\end{array}$ & Phoenix High & $\begin{array}{l}\text { Phoenix Mid- } \\
\text { Range }\end{array}$ & Phoenix Average & Phoenix Low \\
\hline \multirow[t]{2}{*}{ Supporting } & $\begin{array}{l}\text { Adding to soil } \\
\text { life by high } \\
\text { level of plant } \\
\text { abundance }\end{array}$ & $\begin{array}{l}\text { Adding to soil } \\
\text { life by high } \\
\text { level of plant } \\
\text { abundance }\end{array}$ & $\begin{array}{l}\text { Organic matter and } \\
\text { weeds as nutrients } \\
\text { for soil }\end{array}$ & \\
\hline & $\begin{array}{l}\text { Adding to } \\
\text { biodiversity } \\
\text { of the region }\end{array}$ & $\begin{array}{l}\text { Functional } \\
\text { connectivity } \\
\text { to native } \\
\text { environment }\end{array}$ & & \\
\hline \multirow[t]{4}{*}{ Regulating } & $\begin{array}{l}\text { Cooler oasis } \\
\text { micro-climates } \\
\text { through } \\
\text { lawns and trees }\end{array}$ & $\begin{array}{l}\text { Dust-prevention } \\
\text { through lush } \\
\text { plantation }\end{array}$ & $\begin{array}{l}\text { Decomposed granite } \\
\text { and green coverage } \\
\text { preventing soil- } \\
\text { erosion and dust. }\end{array}$ & $\begin{array}{l}\text { No visible irrigation: } \\
\text { saving of water }\end{array}$ \\
\hline & $\begin{array}{l}\text { Dust-prevention } \\
\text { through lush } \\
\text { plantation }\end{array}$ & $\begin{array}{l}\text { Low water run-off } \\
\text { during monsoon } \\
\text { season }\end{array}$ & $\begin{array}{l}\text { Cooler micro-climates } \\
\text { through lawns and } \\
\text { trees }\end{array}$ & \\
\hline & $\begin{array}{l}\text { Low water run-off } \\
\text { during } \\
\text { monsoon season }\end{array}$ & $\begin{array}{l}\text { Shady places } \\
\text { through } \\
\text { adobe-walls }\end{array}$ & $\begin{array}{l}\text { Trees contributing to } \\
\text { air quality close to } \\
\text { highway }\end{array}$ & \\
\hline & & & Water retention & \\
\hline \multirow[t]{2}{*}{ Provisioning } & $\begin{array}{l}\text { Habitat \& food for } \\
\text { many animal } \\
\text { species: native } \\
\text { and exotic }\end{array}$ & $\begin{array}{l}\text { Habitat \& food for } \\
\text { many animal } \\
\text { species: } \\
\text { especially native }\end{array}$ & Native wild food & \\
\hline & $\begin{array}{l}\text { Irrigation attracts } \\
\text { birds and insects }\end{array}$ & & $\begin{array}{l}\text { Irrigation attracts } \\
\text { birds and insects }\end{array}$ & \\
\hline \multirow[t]{5}{*}{ Cultural } & $\begin{array}{l}\text { High contrast to } \\
\text { desert }\end{array}$ & $\begin{array}{l}\text { Ideal of } \\
\text { contributing } \\
\text { to native } \\
\text { environment }\end{array}$ & & $\begin{array}{l}\text { Social encounter \& } \\
\text { family life }\end{array}$ \\
\hline & Aesthetic diversity & Aesthetic diversity & & Low maintenance \\
\hline & $\begin{array}{l}\text { Expression of } \\
\text { historic values }\end{array}$ & $\begin{array}{c}\text { Rehabilitation of } \\
\text { desert image }\end{array}$ & & costs \\
\hline & $\begin{array}{l}\text { Higher property } \\
\text { value }\end{array}$ & $\begin{array}{l}\text { Higher property } \\
\text { value }\end{array}$ & & \\
\hline & Feeling of safety & $\begin{array}{l}\text { Privacy (adobe } \\
\text { walls) }\end{array}$ & & \\
\hline
\end{tabular}

Ecosystem dis-services in front-yards in four neighbourhoods in Phoenix

\begin{tabular}{|c|c|c|c|c|}
\hline $\begin{array}{r}\text { Ecosystem } \\
\text { Services }\end{array}$ & Phoenix High & Phoenix Mid-Range & Phoenix Average & Phoenix Low \\
\hline Supporting & & $\begin{array}{l}\text { Fragmentation and loss } \\
\text { of structural }\end{array}$ & $\begin{array}{l}\text { Bare soils: dust } \\
\text { and erosion }\end{array}$ & $\begin{array}{l}\text { Bare soils: dust and } \\
\text { erosion }\end{array}$ \\
\hline
\end{tabular}




\begin{tabular}{|c|c|c|c|c|}
\hline & $\begin{array}{l}\text { Decreasing soil life by use of } \\
\text { pesticides and artificial } \\
\text { fertilizers on lawns. }\end{array}$ & $\begin{array}{l}\text { connectivity through } \\
\text { high presence of } \\
\text { adobe walls. }\end{array}$ & & \\
\hline & $\begin{array}{l}\text { Non-native species: less } \\
\text { contribution to functional } \\
\text { connectivity of native } \\
\text { environment. }\end{array}$ & $\begin{array}{l}\text { Low soil life through } \\
\text { low plant abundance } \\
\text { and xeric soil cover } \\
\text { structures }\end{array}$ & $\begin{array}{l}\text { Low soil life in } \\
\text { bare soil yards }\end{array}$ & \\
\hline \multirow[t]{3}{*}{ Regulating } & \multirow{3}{*}{$\begin{array}{l}\text { Water pollution through use of } \\
\text { pesticides and artificial } \\
\text { fertilizer on lawns }\end{array}$} & Urban heat island effect & $\begin{array}{l}\text { Urban heat island } \\
\text { effect }\end{array}$ & $\begin{array}{l}\text { Urban heat island } \\
\text { effect }\end{array}$ \\
\hline & & Risk of over-irrigation & $\begin{array}{l}\text { 'Deserts within a } \\
\text { desert' }\end{array}$ & 'Deserts within a desert' \\
\hline & & & Dust & Dust \\
\hline Provisioning & $\begin{array}{l}\text { Disturbance of habitat through } \\
\text { strong maintenance } \\
\text { Light pollution disturbance } \\
\text { Water sustainability issues }\end{array}$ & $\begin{array}{l}\text { Light pollution } \\
\text { disturbance }\end{array}$ & $\begin{array}{l}\text { Light pollution } \\
\text { disturbance }\end{array}$ & $\begin{array}{l}\text { Disturbance by intensive } \\
\text { social use with lack } \\
\text { of care for biotic } \\
\text { environment. }\end{array}$ \\
\hline \multirow[t]{2}{*}{ Cultural } & $\begin{array}{l}\text { High maintenance needs and } \\
\text { costs }\end{array}$ & $\begin{array}{l}\text { Low social interaction } \\
\text { through adobe walls }\end{array}$ & $\begin{array}{l}\text { Potential of } \\
\text { negative image } \\
\text { of } \\
\text { neighbourhood } \\
\text { and } \\
\text { dropping } \\
\text { property value } \\
\text { through lower } \\
\text { maintenance/ } \\
\text { care in some } \\
\text { yards }\end{array}$ & $\begin{array}{l}\text { Negative image of } \\
\text { neighbourhood and } \\
\text { dropping property } \\
\text { value through lower } \\
\text { maintenance/care in } \\
\text { most yards }\end{array}$ \\
\hline & $\begin{array}{l}\text { Social pressure on } \\
\text { maintenance through } \\
\text { Home Owner Associations }\end{array}$ & & $\begin{array}{l}\text { In green gardens: } \\
\text { high } \\
\text { maintenance } \\
\text { needs and costs }\end{array}$ & $\begin{array}{l}\text { Feeling of safety for } \\
\text { visitors }\end{array}$ \\
\hline \multicolumn{5}{|c|}{ Ecosystem services in front-yards in four neighbourhoods in Maastricht } \\
\hline $\begin{array}{l}\text { Ecosystem } \\
\text { Services }\end{array}$ & Maastricht High & Maastricht Mid-Range & Maastricht Average & Maastricht Low \\
\hline \multirow[t]{3}{*}{ Supporting } & $\begin{array}{l}\text { Functional connectivity } \\
\text { to nature park Sint } \\
\text { Pietersberg }\end{array}$ & $\begin{array}{l}\text { Structural connectivity } \\
\text { to nature } \\
\text { park Savelsbos }\end{array}$ & $\begin{array}{l}\text { Diversity of yard } \\
\text { styles } \\
\text { contributes } \\
\text { to biodiversity }\end{array}$ & \\
\hline & Rich soil life & & $\begin{array}{l}\text { Functional and } \\
\text { structural } \\
\text { connectivity to } \\
\text { Savelsbos }\end{array}$ & \\
\hline & High (native) biodiversity & & $\begin{array}{l}\text { Diversity of soil } \\
\text { structures }\end{array}$ & \\
\hline \multirow[t]{3}{*}{ Regulating } & High permeability & Overall permeable soil & $\begin{array}{l}\text { Little private trees } \\
\text { but abundance } \\
\text { of public } \\
\text { trees reduce } \\
\text { noise and } \\
\text { air pollution } \\
\text { from nearby } \\
\text { highway. }\end{array}$ & $\begin{array}{l}\text { Little private trees but } \\
\text { public trees reduce } \\
\text { noise and air } \\
\text { pollution } \\
\text { from city centre. }\end{array}$ \\
\hline & $\begin{array}{l}\text { Strong water-retention poten- } \\
\quad \text { tial }\end{array}$ & Water retention & $\begin{array}{l}\text { Water retention } \\
\text { diversified }\end{array}$ & \\
\hline & & $\begin{array}{l}\text { High carbon capture in } \\
\text { young trees }\end{array}$ & & \\
\hline
\end{tabular}



Air quality improvement close to city centre and major road.

Provisioning Food and habitat for native species

Cultural Aesthetic diversity

Space for individual expression

Social encounter

Good property value

Close to city, close to nature
Feeling of safety

Habitat through hedges Food \& habitat and (berry) shrubs

Status through aesthetic Green image 'uniformity'

Image of neatness and tidiness while living close to nature

Property value

Medium maintenance needs diversity

Many bird nesting facilities

Social encounter

Leisure time

expression and creativity

Multiple services by diversity of gardens

Educational

Low maintenance need services

Social encounter

Low maintenance costs

\begin{tabular}{|c|c|c|c|c|}
\hline $\begin{array}{l}\text { Ecosystem } \\
\text { Services }\end{array}$ & Maastricht High & Maastricht Mid-Range & Maastricht Average & Maastricht Low \\
\hline Supporting & $\begin{array}{l}\text { Less soil nutrients } \\
\text { through high } \\
\text { maintenance levels }\end{array}$ & $\begin{array}{l}\text { Less soil nutrients through high } \\
\text { maintenance levels } \\
\text { Monotonous use of popular } \\
\text { plants, low flower } \\
\text { abundance, low diversity. }\end{array}$ & $\begin{array}{l}\text { Dis-contribution to soil } \\
\text { life by high amount } \\
\text { of paved yards. }\end{array}$ & $\begin{array}{l}\text { Dis-contribution to soil } \\
\text { life by high amount } \\
\text { of paved yards. }\end{array}$ \\
\hline Regulating & $\begin{array}{l}\text { Potential of invasive alien } \\
\text { species spreading to } \\
\text { proximate nature }\end{array}$ & $\begin{array}{l}\text { Water run-off in many paved } \\
\text { sections }\end{array}$ & $\begin{array}{l}\text { Water run-off in many } \\
\text { paved sections } \\
\text { Local urban heat island } \\
\text { effect } \\
\text { Desertification of parts } \\
\text { of neighbourhood }\end{array}$ & $\begin{array}{l}\text { Water run-off in many } \\
\text { paved sections } \\
\text { Local urban heat island } \\
\text { effect } \\
\text { Desertification of parts } \\
\text { of neighbourhood }\end{array}$ \\
\hline Provisioning & $\begin{array}{l}\text { Disturbances by bicycles } \\
\text { in yards. }\end{array}$ & $\begin{array}{c}\text { Disturbances by car-parking, } \\
\text { use of machines to trim } \\
\text { hedges, high maintenance. }\end{array}$ & $\begin{array}{l}\text { Disturbance by car- } \\
\text { parking and social } \\
\text { use }\end{array}$ & $\begin{array}{l}\text { Disturbance by car- } \\
\text { parking and social } \\
\text { use } \\
\text { Light pollution }\end{array}$ \\
\hline \multirow[t]{3}{*}{ Cultural } & & $\begin{array}{l}\text { Little individual expression \& } \\
\text { creativity, complying to a } \\
\text { neat and tidy image. }\end{array}$ & $\begin{array}{l}\text { Grey image } \\
\text { Lower property value }\end{array}$ & $\begin{array}{l}\text { Grey image } \\
\text { Lower property value }\end{array}$ \\
\hline & & $\begin{array}{l}\text { Distinction from proximate } \\
\text { natural landscape }\end{array}$ & $\begin{array}{l}\text { Potential lack of feeling } \\
\text { safe }\end{array}$ & $\begin{array}{l}\text { Potential lack of feeling } \\
\text { safe }\end{array}$ \\
\hline & & $\begin{array}{l}\text { Annoyance from maintenance } \\
\text { machine use. }\end{array}$ & $\begin{array}{l}\text { Potential annoyance by } \\
\text { 'green litter' of } \\
\text { municipal plantation. } \\
\text { Annoyance from noise } \\
\text { of municipal green } \\
\text { maintenance. }\end{array}$ & \\
\hline
\end{tabular}


Open Access This article is distributed under the terms of the Creative Commons Attribution 4.0 International License (http://creativecommons.org/licenses/by/4.0/), which permits unrestricted use, distribution, and reproduction in any medium, provided you give appropriate credit to the original author(s) and the source, provide a link to the Creative Commons license, and indicate if changes were made.

\section{References}

Ahrends HE, Etzold S, Kutsch WL, Stoeckli R, Bruegger R, Jeanneret F, Wanner H, Buchmann N, Eugster W (2009) Tree phenology and carbon dioxide fluxes: use of digital photography for process-based interpretation at the ecosystem scale. Clim Res 39:261-274

Alcoforado MJ, Andrade H (2008) Global warming and the urban heat island. In: Marzluf JM, Schulenberger E, Endlicher W, Alberti M, Bradley G, Ryan C, Simon U, ZumBrunnen C (eds) Urban ecology. An international perspective on the interaction between humans and nature. Springer, New York

Appleton AF (2002) How New York city used an ecosystem services strategy carried out through an urban-rural partnership to preserve the pristine quality of its drinking water and save billions of dollars and what lessons it teaches about using ecosystem services. Paper presented at the The Katoomba Conference

Baker PJ, Harris S (2007) Urban mammals: what does the future hold? An analysis of the factors affecting patterns of use in residential gardens in Great Britain. Mammal Rev 37:297-315

Banerjee SB (2003) Who sustains whose development? Sustainable development and the reinvention of nature. Organ Stud 24(1):143-180

Beatley T (2011) Biophilic cities. Integrating nature into urban design. Island Press, Washington D.C

Beck JL, Booth TD, Kennedy CL (2014) Assessing greater sage-grouse breeding habitat with aerial and ground imagery. Rangel Ecol Manag 67(3):328-332

Beumer C (2014) Stepping stone cities? Exploring urban greening and gardening as a viable contribution to global biodiversity conservation. Maastricht University, Maastricht

Beumer C, Martens P (2015) Biodiversity in my (back) yard: a framework for assessing ecosystem services and biodiversity in residential gardens. Sustain Sci 10(1):87-100

Bolund P, Hunhammar S (1999) Ecosystem services in urban areas. Ecol Econ 29:293-301

Burghardt KT, Tallamy DW, Shriver G (2008) Impact of native plants on bird and butterfly biodiversity in suburban landscapes. Conserv Biol 23(1):219-224

Caro T (2010) Conservation by proxy. Indicator, umbrella, keystone, flagship, and other surrogate species. Island Press, London

Castro CJ (2004) Sustainable development: mainstream and critical perspectives. Organ Environ 17(195):195225

CBD (2007) Cities and biodiversity. Paper presented at the Conference of the Parties 9, 2007, Curitiba

CBD (2010) Global biodiversity outlook 3. Convention on Biological Diversity, Montreal

CBS (2013) Bevolking; ontwikkeling in gemeenten met 100000 of meer inwoners. http://statline.cbs.nl/ StatWeb/publication/?VW=T\&DM=SLNL\&PA=70748NED\&D1=0,2,4,16,18,20,22,24\&D2=a\&D3= 0\&D4=a\&D5=1\&HD=090707-1905\&HDR=T\&STB=G4,G2,G1,G3, retrieved 17 August 2015

Chou W-Y, Chang C-Y, Sullivan WC (2011) Environmental qi field qualities of different landscape structures. Paper presented at the IFLA APR Congress - Hospitality: The Interaction with Land

Chowdhury RR, Larson K, Grove M, Polsky C, Cook E (2011) A multi-scalar approach to theorizing socioecological dynamics of urban residential landscapes. Cities Environ 4(1):1-19

Cilliers S (2010) Social aspects of urban biodiversity—an overview. In: Müller N, Werner P, Kelcey JG (eds) Urban biodiversity and design. Wiley-Blackwell, London

Cook EM, Hall SJ, Larson KL (2012) Residential landscapes as social-ecological systems: a synthesis of multiscalar interactions between people and their home environment. Urban Ecosyst 15:19-52

Cornelis J, Hermy M (2004) Biodiversity relationships in urban and suburban parks in Flanders. Landsc Urban Plan 69:385-401

Costanza R, D'Arge R, De Groot R (1997) The value of the world's ecosystem services and natural capital. Nature 387:253-260

Costanza R, De Groot R, Sutton P, Van der Ploeg S, Andersond SJ, Kubiszewski I, Farber S, Turner RK (2014) Changes in the global value of ecosystem services. Glob Environ Chang 26:152-158

Cranz G, Boland M (2004) Defining the sustainable park: a fifth model for urban parks. Landsc J 23(2):102-120

DBG (2013) Desert botanical garden. Retrieved 9 August 2013, from http://www.dbg.org/ 
Dearborn DC, Kark S (2009) Motivations for conserving urban biodiversity. Conserv Biol 24(2):432-440

DesJardins J (2006) Environmental ethics. An introduction to environmental philosophy, 4th edn. Thomson Wadsworth, Belmont

Dresner S (2002) The principles of sustainable development. Earthscan, London/Sterling

Dunn RR, Gavin MC, Sanchez MC, Solomon JN (2006) The pigeon paradox: dependence of global conservation on urban nature. Conserv Biol 20(6):1814-1816

Ewing R (2001) Using a visual preference survey in transit design. Public Works Manag Policy 5(270):270-280

Fairview (2009) Retrieved 24 May 2013, from www.fairviewplace.org

Farinha-Marques P, Lameiras JM, Fernandes C, Silva S, Guilherme F (2011) Urban biodiversity: a review of current concepts and contributions to multidisciplinary approaches. Innovation: The European Journal of Social Science Research 24(3):247-271

Folke C, Carpenter S, Walker B, Scheffer M, Elmqvist T, Gunderson L, Holling CS (2004) Regime shifts, resilience, and biodiversity in ecosystem management. Annu Rev Ecol Evol Syst 35:557-581

Galluzzi G, Eyzaguirre P, Negri V (2010) Home gardens: neglected hotspots of agro-biodiversity and cultural diversity. Biodivers Conserv 19:3635-3654

Gaston KJ, Warren PH, Thompson K, Smith RR (2005) Urban domestic gardens (IV): the extent of the resource and its associated features. Biodivers Conserv 14:3327-3349

Giddings B, Hopwood B, O’Brien G (2002) Environment, economy, and society: fitting them together into sustainable development. Sustain Dev 10:187-196

Goddard MA, Dougill AJ, Benton TG (2010) Scaling up from gardens: biodiversity conservation in urban environments. Trends Ecol Evol 25(2):90-99

Groot RSD, Wilson MA, Boumans RMJ (2002) A typology for the classification, description and valuation of ecosystem function, goods and services. Ecol Econ 41(3):393-408

Gunderson LH, Holling CS (eds) (2002) Panarchy. Understanding transformations in human and natural systems. Island Press, Washington

Hancock J (2010) The case for an ecosystem service approach to decision-making: an overview. Biosci Horiz $3(2): 188-196$

Hart JL (2007) Biodiversity and edge effects: an activity in landscape ecology. J Nat Resour Life Sci Educ 36: 103-106

Heezik YV, Dickinnson KJM, Freeman C (2012) Closing the gap: communicating to change gardening practices in support of native biodiversity in urban private gardens. Ecol Soc 17(1):34

Hemenway T (2009) Gaia's garden: a guide to home-scale permaculture. Chelsea Green Publishing Company, White River Junction

Hermy M, Cornelis J (2000) Towards a monitoring method and a number of multifaceted and hierarchical biodiversity indicators for urban and suburban parks. Landsc Urban Plan 49(3-4):149-162

Hope D, Gries C, Casagrande D, Redman CL, Grimm N, Martin C (2006) Drivers of spatial variation in plant diversity across the Central Arizona - Phoenix ecosystem. Soc Nat Resour 19:101-116

Hopper F (1981) The Dutch Régence garden. Gard Hist 9(2):118-135

Huynen M (2008) Future health in a globalising world. Maastricht University Press, Maastricht

Huynen MMTE, Martens P, De Groot RS (2004) Linkages between biodiversity loss and human health: a global indicator analysis. Int J Environ Health Res 14(1):13-30

Ignatieva M (2010) Design and future of urban biodiversity. In: Mueller N, Werner P, Kelcey JG (eds) Urban biodiversity and design. Blackwel Publishers Ltd., Oxford

Ignatieva M, Stewart GH, Meurk C (2011) Planning and design of ecological networks in urban areas. Landsc Ecol Eng 7(Biodiversity and Ecosystem Services: Importance of Cities for post 2010 perspective):17-25

IPCC (2013) Climate change 2013. The physical science base. Summary for policymakers. Intergovernmental Panel on Climate Change, Switzerland

IUCN (2013) About biodiversity. Retrieved 8 July 2013, from www.iucn.org/what/biodiversity/about/?gclid= CP7Hr9r4n7gCFdDJtAodeEEACg

Jaganmohan M, Vailshery LS, Gopal D, Nagendra H (2012) Plant diversity and distribution in urban domestic gardens and apartments in Bangalore, India. Urban Ecosyst 15:911-925

Jim CY (2012) Sustainable urban greening strategies for compact cities in developing and developed countries. Urban Ecosyst

Jorgensen A, Keenan R (2012) Urban wildscapes. Routledge, New York

Kaplan S (1995) The restorative benefits of nature. J Environ Psychol 15:169-182

Kendal D, Williams NSG, Williams KJH (2012) A cultivated environment: exploring the global distribution of plants in gardens, parks and streetscapes. Urban Ecosyst 15:637-652

Keylock CJ (2005) Simpson diversity and the Shannon/Wiener index as special cases of a generalized entropy. Oikos 109(1):203-207 
Khachatryan H, Zhou G (2014) Preferences for sustainable lawn care practices: the choice of lawn fertilizers. Paper presented at the Agricultural \& Applied Economics Association's 2014 Annual Meeting

Kirmer A, Tischew S (2010) Near-natural restoration strategies in post-mining landscapes. In: Müller N, Werner P, Kelcey JG (eds) Urban biodiveristy and design. Blackwell Publishing Ltd., Oxford

Kurz T, Baudains C (2012) Biodiversity in the front yard: an investigation of landscape preference in a domestic urban context. Environ Behav 44(166):166-196

Lang DJ, Wiek A, Bergmann M, Stauffacher M, Martens P, Moll P, Swilling M, Thomas CJ (2012) Transdiciplinary research in sustainability science: practice, principles, and challenges. Sustain Sci 7(Supplement 1):25-43

Larsen L, Harlan SL (2006) Desert dreamscapes: residential landscape preference and behavior. Landsc Urban Plan 78:85-100

Larsen L, Swanbrow L (2006) Postcards of Phoenix: images of desert ambivalence and homogeneity. Landsc J 25(2-6):205-217

Larson KL, Casagrande D, Harlan S, Yabiku ST (2009) Residents' yard choices and rationales in a Desert City: social priorities, ecological impacts, and decision tradeoffs. Environ Manag 44:921-937

Larson KL, Cook E, Strawhacker C, Hall SJ (2010) The influence of diverse values, ecological structure, and geographic context on residents'multifaceted landscaping decisions. Hum Ecol 38:747-761

Lewanzik D, Voigt CC (2014) Artificial light puts ecosystem services of frugivorous bats at risk. J Appl Ecol 51(2):388-394

Lohr VI (2007) Benefits of nature: what we are learning about why people respond to nature. J Physiol Anthropol 26:83-85

Loram A, Warren PH, Gaston KJ (2008) Urban domestic gardens (XIV): the characteristics of gardens in five cities. Environ Manag 42:361-376

Lowe E, Wilder S, Hochuli D (2014) Urbanisation at multiple scales is associated with larger size and higher fecundity of an orb-weaving spider. PLoS ONE 9(8)

Lubbe CS, Siebert SJ, Cilliers SS (2010) Political legacy of South Africa affects the plant diversity patterns of urban domestic gardens along a socio-economic gradient. Sci Res Essays 5(19):2900-2910

Lyytimäki J, Petersen LK, Normander B, Bézak P (2008) Nature as nuisance? Ecosystem services and disservices to urban lifestyle. Environ Sci 5(3):161-172

Maas J, Verheij RA, Groenewegen PP, Vries SD, Spreeuwenberg P (2006) Green space, urbanity, and health: how strong is the relation? J Epidemiol Community Health 60:587-592

Martens P (2006) Sustainability: science or fiction? Sust Sci Pract Pol 2(1):36-41

Martin CA (2008) Landscape sustainability in a Sonoran Desert City. Cities Environ 1(2):1-16

Mathieu R, Freeman C, Aryal J (2007) Mapping private gardens in urban areas using object-oriented techniques and very high-resolution satellite imagery. Landsc Urban Plan 81:179-192

McKinney ML (2002) Urbanization, biodiversity, and conservation. Bioscience 52(10):883-890

McNeely JA, Faith DP, Albers HJ, Dulloo E, Goldstein W, Groombridge B (2005) Millennium Ecosystem assessment. Assessment of policy responses

MEA (2005) Ecosystems and human well-being. Biodiversity synthesis. World Resources Institute, Washington, $\mathrm{DC}$

Mee WR (2011) Highlights of the city of Phoenix water conservation program

Meijer SA, Van Timmeren A, Crul MRM, Brezet HC (2013) From community resilience towards urban resilience: exploring the grassroot initiatives' role in cities. Paper presented at the Livinggreen Scientific Conference, Delft

Miller JR, Hobbs RJ (2002) Conservation where people live. Conserv Biol 16(2):330-337

Mitchell DB, Mueller MP (2009) A philosophical analysis of David Orr's theory of ecological literacy: biophilia, ecojustice and moral education in school learning communities. Cult Stud Sci Educ 6:193-221

Mitchell MGE, Bennett EM, Gonzalez A (2013) Linking landscape connectivity and ecosystem service provision: current knowledge and research gaps. Ecosystems 16(5):894-908

Mollison B (1988) Permaculture. A designers' manual. Tagari Publications, Tyalgum

Müller N, Kamada M (2011) URBIO: an introduction to the international network in urban biodiversity and design. Landsc Ecol Eng 7(1):1-8

Müller N, Werner P, Kelcey JG (eds) (2010) Urban biodiversity and design, vol 7. Wiley-Blackwell, Oxford

Nagendra H (2002) Opposite trends in response for the Shannon and Simpson indices of landscape diversity. Appl Geogr 22(2):175-186

Nasar JL (2011) Environmental psychology and urban design. In: Banerjee T, Loukaitou-Sideris A (eds) Companion to urban design. Routledge, New York, pp 162-171

Nassauer JI (1995) Messy ecosystems. Orderly frames. Landsc J 14(2):161-170

Newman PWG (1999) Sustainability and cities: extending the metabolism model. Landsc Urban Plan 44:219-226

Norris-Bernzel K, Edinger P (2005) Gardening in the Southwest. Sunset Publishing Corporation, Menlo Park 
Norton BG, Noonan D (2007) Ecology and valuation: big changes needed. Ecol Econ 63:664-675

Noss RF (1990) Indicators for monitoring biodiversity: a hierarchical approach. Conserv Biol 4(4):355-364

Nunes P, van den Bergh J (2001) Economic valuation of biodiversity: sense or nonsense? Ecol Econ 39:203-222

NWF (2013) Garden for wildlife. Make habitat at home. Retrieved 30 July 2013, from http://www.nwf.org/Howto-Help/Garden-for-Wildlife.aspx?campaignid=WH10DGWP\&s_src=CWH_Wildlife_Navigation

Olsson P, Folke C (2007) Adaptive comanagement for building resilience in social-ecological systems. Environ Manag 34(1):75-90

Opschoor JB (1998) The value of ecosystem services: whose values? Ecol Econ 25:41-43

Orians GH (1980) Habitat selection: general theory and applications to human behavior. In: Lockard SJ (ed) The evolution of human social behavior. Elsevier, New York

Pallant J (2005) SPSS survival manual. a step by step guide to data analysis usiong SPSS version 12. Open University Press \& McGraw-Hill, New York

Pearsall H, Pierce J (2010) Urban sustainability and environmental justice: evaluating the linkages in public planning/policy discourse. Local Environ 15(6):569-580

Perkin EK, Hölker F, Tockner K, Richardson JS (2014) Artificial light as a disturbance to light-naïve streams. Freshw Biol 59(11):2235-2244

Qviström M (2013) Searching for an open future: planning history as a means of peri-urban landscape analysis. J Environ Plan Manag

R. SH, VanLeeuwen DM, Torres P (2010) Landscape preferences and water conservation choices of residents in a high desert environment. HortTechnology 20(2):308-314

Rahola BS, Oppen, PV, Mulder K (2014) Heat in the city: an inventory of knowledge and knowledge deficiencies regarding heat stress in Dutch cities and options for its mitigation. Klimaat voor Ruimte

Rees WE (2010) Thinking 'resilience'. In: Heinberg R, Lerch D (eds) The post carbon reader: managing the 21st century's sustainability crises. Watershed Media, Post Carbon Institute, Santa Rosa

Rees W, Wackernagel M (2008) Urban ecological footprints: why cities cannot be sustainable - and why they are a key to sustainability. In: Marzluf JM, Shulenberger E, Endlicher W, Alberti M, Bradley G, Ryan C, Simon U, ZumBrunnen C (eds) Urban ecology. Springer, New York

Robinson J (2004) Squaring the circle? Some thoughts on the idea of sustainable development. Ecol Econ 48(4): 369-384

Rosenzweig ML (2003) Reconciliation ecology and the future of species diversity. Oryx 37(2):194-205

Rudd H, Vala J, Schaefer V (2002) Importance of backyard habitat in a comprehensive biodiversity conservation strategy: a connectivity analysis of urban green spaces. Restor Ecol 10(2):368-375

Savard JPL (2000) Biodiversity concepts and urban ecosystems. Landsc Urban Plan 48(3-4):131-142

Schulz M (1985) Paradise preserved: recreations of Eden in eighteenth and nineteenth century England. Cambridge University Press, New York

Shin HB (2012) Looking back and ahead: lessons from the 2008 Beijing Olympic Games. http://eprints.lse.ac.uk/ 46544/1/blogs.1se.ac.uk-Looking_back_and_ahead_Lessons_from_the_2008_Beijing_Olympic_Games.pdf

Simonis UE (2011) Greening urban development: on climate change and climate policy. Int J Soc Econ 38(11): 919-928

Smetana SM, Crittenden JC (2014) Sustainable plants in urban parks: a life cycle analysis of traditional and alternative lawns in Georgia, USA. Landsc Urban Plan 122:140-151

Spellerberg IF, Ferdor PJ (2003) A tribute to Claude Shannon (1916-2001) and a plea for more rigorous use of species richness, species diversity and the 'Shannon-Wiener' index. Glob Ecol Biogeogr 12:177-179

Steffen W, Sanderson A, Tyson PD, Jaeger J, Matson PA, Moore B III, Oldfield F, Richardson K, Schellnhuber HJ, Turner BL II, Wasson RJ (2005) Global change and the earth system: a planet under pressure. Springer, Berlin

Stone EL, Jones G, Harris S (2012) Conserving energy at a cost to biodiversity? Impacts of LED lighting on bats. Glob Chang Biol 18(8):2458-2465

Sukopp H (2008) On the early history of urban ecology in Europe. In: Marzluf JM, Bradley G, Shulenberger E, Endlicher W, Alberti M, Ryan C, Simon U, ZumBrunnen C (eds) Urban ecology. Springer, New York, pp 79-97

Szilagy K (2011) The evolution of english picturesque landscape garden to urban public park. Paper presented at the First International Conference "Horticulture and Landscape Architecture in Transylvania"

TEEB (2009) The economics of ecosystems and biodiversity for national and international policy makers: summary: responding to the value of nature. UNEP, Bonn

TEEB (2011) TEEB manual for cities: ecosystem services in urban management. TEEB.

Theeuwes NE, Steeneveld GJ, Ronda RJ, Heusinkveld BG, Holtslag AAM (2012) Mitigation of the urban heat island effect using vegetation and water bodies. Paper presented at the 8th Int. Conf. Urban Climate

Tidball KG (2012) Urgent biophilia: human-nature interactions and biological attractions in disaster resilience. Ecol Soc 17(2):5 
Tint P, Tarmas G, Koppel T, Reinhold K, Kalle S (2012) Vibration and noise caused by lawn maintenance machines in association with risk to health. Agron Res Biosyst Eng 1:251-260

Tzoulas K, James P (2010) Making biodiversity measures accessible to non-specialists: an innovative method for rapid assessment of urban biodiversity. Urban Ecosyst 13:113-127

UNEP (2014) World urbanization prospects. The 2014 revision. UNEP

Uren HV, Dzidic PL, Bishop BJ (2015) Exploring social and cultural norms to promote ecologically sensitive residential garden design. Landsc Urban Plan 137:76-84

USCB (2013) Quick facts Beta United States. http:/quickfacts.census.gov/qfd/states/04/0455000.html. Retrieved at 17 August 2015

Van den Berg AE, Jorgensen A, Wilson ER (2014) Evaluating restoration in urban green spaces: does setting type make a difference? Landsc Urban Plan 127:173-181

Vellend M, Brown CD, Kharouba HM, McCune JL, Myers-Smith IH (2013) Historical ecology: using unconventional data sources to test for effects of global environmental change. Am J Bot 100(7):1294-1305

White R, Sasser D, Bogren R, Morgan J (2009) Photos can inspire a thousand words: photolanguage as a qualitative evaluation method. J Ext 47(3)

Whittaker RJ, Fernandez-Palacios JM (2007) Island biogeography: ecology, evolution, and conservation. Oxford University Press, Oxford

Wiek A, Ness B, Schweizer-Ries P, Brand FS, Farioli F (2012) From complex systems analysis to transformational change: a comparative appraisal of sustainability science projects. Sustain Sci 7(Supplement 1):5-24

Williams CC, Millington AC (2004) The diverse and contested meanings of sustainable development. Geogr J 170(2):99-104

Woonpunt (2012) Kunstproject met vogelhuisjes fleurt buurt op. Nieuws van Woonpunt

Zarco-Tejada PJ, Diaz-Varela R, Angileri V, Loudjani P (2013) Tree height quantification using very high resolution imagery acquired from an unmanned aerial vehicle (UAV) and automatic 3D photo-reconstruction methods. Eur J Agron 55:89-99

Zerbe S, Maurer U, Schmitz S, Sukopp H (2003) Biodiversity in Berlin and its potential for nature conservation. Landsc Urban Plan 62:139-148

Zheng B, Zhang Y, Chen J (2011) Preference to home landscape: wildness or neatness? Landsc Urban Plan 99:18

Zube EH, Simcox DE, Law CS (1986) The oasis image of two desert cities. Landsc Res 11(3):7-11

Zwaagstra C (2014) The contribution of soil sealing in urban private gardens to runoff and urban heating. Rijksuniversiteit Groningen, Groningen 